\title{
Extracts of Bridelia ovata and Croton oblongifolius induce apoptosis in human MDA-MB-231 breast cancer cells via oxidative stress and mitochondrial pathways
}

\author{
JUTHATHIP POOFERY ${ }^{1}$, BUNGORN SRIPANIDKULCHAI ${ }^{2}$ and RATANA BANJERDPONGCHAI ${ }^{1}$ \\ ${ }^{1}$ Department of Biochemistry, Faculty of Medicine, Chiang Mai University, \\ Chiang Mai 50200; ${ }^{2}$ Center for Research and Development of Herbal Health Products, Faculty \\ of Pharmaceutical Sciences, Khon Kaen University, Khon Kaen 40002, Thailand
}

Received July 4, 2019;Accepted December 12, 2019

DOI: $10.3892 /$ ijo.2020.4973

\begin{abstract}
Breast cancer is the most common type of cancer and is also the second leading cause of cancer-associated death in women worldwide. Thus, there is an urgent requirement for the development of effective treatments for this disease. Bridelia ovata and Croton oblongifolius are herbs used in Thai traditional medicine that have been used to treat various health problems; $B$. ovata has traditionally been used as a purgative, an antipyretic, a leukorrhea treatment and as a birth control herb. $C$. oblongifolius has been used to increase breast milk production, for post-partum care (where it is used as a hot bath herb), and as a treatment for flat worms and dysmenorrhea. However, there is little research investigating the anticancer properties of these herbs. The present study aimed to investigate the anticancer properties of crude ethyl acetate extracts of B. ovata (BEA) and C. oblongifolius (CEA) in order to explore their underlying mechanisms in breast cancer cell death. The phytoconstituents of the crude extracts of BEA and CEA were studied using gas chromatography-mass spectrometry (GC-MS). GC-MS analysis showed that the primary compound in BEA is friedelan-3-one, and kaur-16-en-18-oic acid in CEA. Cytotoxicity was investigated using an MTT assay, both BEA and CEA showed greater toxicity against MDA-MB-231
\end{abstract}

Correspondence to: Dr Ratana Banjerdpongchai, Department of Biochemistry, Faculty of Medicine, Chiang Mai University, Chiang Mai 50200, Thailand

E-mail: ratana.b@cmu.ac.th

Abbreviations: BEA, Bridelia ovata ethyl acetate extract; CEA, Croton oblongifolius ethyl acetate extract; $\Delta \Psi \mathrm{m}$, mitochondrial transmembrane potential; NOXA, phorbol-12myristate-13-acetate-induced protein 1 or PMAIP1; BAX, Bcl2-associated X protein; Bcl-xL, B-cell lymphoma-extra large

Key words: Bridelia ovata, Croton oblongifolius, phytochemicals, breast cancer, apoptosis, extract breast cancer cells compared with their effect on MCF10A normal epithelial mammary cells. BEA and CEA exerted various effects, including inducing apoptotic cell death, reducing mitochondrial transmembrane potential, increasing the levels of intracellular ROS, activating caspases, upregulating pro-apoptotic and downregulating anti-apoptotic genes and proteins. BEA and CEA were shown to have anticancer activity against breast cancer cells and induce apoptosis in these cells via a mitochondrial pathway and oxidative stress.

\section{Introduction}

Breast cancer is the most common type of cancer and the leading cause of cancer-associated mortality and morbidity in women worldwide $(1,2)$. The mortality rate for this disease has decreased due to early diagnosis, but treatment outcomes of patients with advanced breast cancer remain poor (3). There are currently several options for the treatment of breast cancer such as surgery, radiotherapy and chemotherapy, but their use is limited by adverse effects, drug resistance and rapid cancer cell metastasis (4). Therefore, an effective treatment for certain aggressive forms of breast cancer, such as inflammatory breast cancer and triple-negative breast cancer (TNBC), is still required. TNBC cannot be treated with hormonal therapy, as TNBC cells do not express receptors for estrogen, progesterone and epidermal growth factor (5). Despite some considerable limitations, the leading cancer treatments have generally improved over the years; though the financial cost remains high (6). Hence, cancer research should move towards developing and applying herbal treatment strategies with lower costs and fewer side effects to patients.

Bridelia ovata and Croton oblongifolius, from the Euphorbiaceae family, are traditional herbs found in Thailand; Thai traditional medicine uses the dried leaf of B. ovata as an expectorant and a laxative, whereas the bark is used as a medicinal astringent (7). Few previous phytochemical studies have demonstrated the presence of triterpenes and phytosterols in $B$. ovata $(8,9)$; its crude ethanolic extract has been shown to inhibit the invasive and migratory abilities of HepG2 cells (10), thus the present study focused on the identification of these compounds in B. ovata. 
C. oblongifolius has been used as a medicinal plant for the treatment of several diseases and ailments; for example, the leaf is used as a blood tonic for general weakness and poor appetite, and the flower is used to treat flatworm infections. Furthermore, the fruit is used to alleviate dysmenorrhea, the seed acts as a purgative (11) and the root is used in the treatment of dysentery (12). In addition, $C$. oblongifolius bark has been used for the treatment of dyspepsia, chronic liver enlargement and remittent fever (13). Moreover, in Thai traditional medicine, C. oblongifolius is utilized in combination with $C$. sublyratus to treat gastric ulcers and gastric cancers $(14,15)$. Several types of phytochemical have been isolated from $C$. oblongifolius, including megastigmane glycosides (16), labdane diterpenoids $(11,17)$, clerodanes (18-21), halimanes (22), cembranes $(21,23,24)$, pimarane-types (acantoic acid) (25) and (-)-ent-kaur-16-en-19-oic acid (12). A study investigating clerodanes from $C$. oblongifolius showed that this phytochemical has cytotoxic effect against human cancer cell lines, including HepG2, SW620, CHAGO, KATO3 and BT474 (17). However, there are currently no reports of the activity of $B$. ovata and $C$. oblongifolius ethyl acetate extracts against TNBC cells, and to the best of our knowledge, the underlying mechanisms mediating the induction of cancer cell death remain unknown.

In the present study, apoptosis (programmed cell death) was investigated. Apoptosis is an important process for normal tissue homeostasis (26), and any disruption of the underlying mechanisms may cause the onset of a variety of diseases, including autoimmunity, neurodegenerative diseases and cancer (27). Therefore, therapeutic strategies targeting apoptosis have been applied to treat these diseases (28). The two primarily routes of apoptosis are the extrinsic and intrinsic pathways; the extrinsic, or death receptor pathway is induced by the binding of death ligands (such as FasL, TRAIL and TNF) to specific receptors (such as FAS, TRAILR1-2 and TNFR1) at the cell membrane (29). Subsequently, the intracellular death domain of the receptor recruits the adaptor FAS-associated death domain protein and the initiator caspase 8 . These form the death-inducing signaling complex (DISC). DISC proteolytically auto-activates caspase 8 , which then cleaves and activates the effector caspase 3 to induce apoptosis $(30,31)$.

The intrinsic, or mitochondrial pathway, is triggered by diverse stimuli, including DNA damage, chemotherapeutic drugs and oxidative stress. These stimuli induce the loss of mitochondrial transmembrane potential, permitting cytochrome $c$ release from the mitochondria intermembranous space into the cytosol, resulting in apoptosome formation. The apoptosome is a protein complex comprising cytochrome $c$, apoptosis-activating factor 1, adenosine triphosphate (ATP), and procaspase-9 (32). The apoptosome autoactivates caspase 9 , which in turn cleaves and activates caspase 3 (33), resulting in apoptosis. Mitochondrial apoptosis is controlled by the $\mathrm{Bcl}-2$ protein family. This comprises anti-apoptotic proteins, including $\mathrm{Bcl}-2, \mathrm{Bcl}-\mathrm{xL}$ and Mcl-1, and two other groups of pro-apoptotic proteins, including the multi-domain proteins BAX and Bcl-2 homologous antagonist/killer (BAK), and BH3-only proteins Bcl-2-like protein 11 (BIM), and phorbol-12-myristate-13-acetate-induced protein 1 (NOXA). During apoptosis, the expression of anti-apoptotic molecules is downregulated, and regulatory $\mathrm{BH} 3$-only proteins induce the formation of transport channels on the outer mitochondrial membrane, comprised of dimers of BAX and/or
BAK (34). These channels promote cytochrome $c$ release and the sequential activation of caspase 9 and 3 (35). Therefore, the aim of the present study was to investigate the pro-apoptotic potential of BEA and CEA against MDA-MB-231 triple-negative breast cancer cells. This cell line has the highest potential for invasiveness (36) and is commonly used as a model for late-stage breast cancer (37).

\section{Materials and methods}

Plant materials. The trunks of B. ovata and C. oblongifolius were collected from northeastern Thailand by the plant genetic conservation project under the Royal Initiative of Her Royal Highness Princess Maha Chakri Sirindhorn (RSPG). The plants were extracted using ethyl acetate as a solvent, and authenticated by Professor Dr. Bungorn Sripanidkulchai (Center for Research and Development of Herbal Health Products, Department of Pharmaceutical Chemistry, Faculty of Pharmaceutical Sciences, Khon Kaen University, Thailand); the voucher numbers of B. ovata and C. oblongifolius are TT-OC-SK-1253 and TT-OC-SK-1215, respectively. The collected plants were washed, cut and dried, and then crushed into powders. The extracts were obtained using ethyl acetate at a plant-to-solvent ratio of 1:5 at room temperature for $72 \mathrm{~h}$, filtered using Whatman filter paper no. 1 and then centrifuged at $500 \mathrm{x}$ g for $10 \mathrm{~min}$ to obtain the supernatant. The extracts were then concentrated under a rotary evaporator and the final products were weighed prior to determination of the percentage yield. For the cell treatment, the crude ethyl acetate extracts were dissolved in dimethyl sulfoxide (DMSO) to obtain an appropriate concentration of the extract stock solutions (to avoid DMSO-associated cellular toxicity). The final concentrations of DMSO under the treatment conditions were less than $0.2 \%$, at which they were not cytotoxic (38).

Reagents and assay kits. The chemicals and solvents used were of analytical grade, which included chloroform, ethyl acetate, ferric chloride, hydrochloric acid, sulfuric acid, acetic acid anhydride, sodium hydroxide, copper acetate, potassium iodide and mercuric chloride (all Merck KGaA). Dulbecco's modified Eagle's medium (DMEM), DMEM/Ham's F-12, fetal bovine serum (FBS), horse serum (HS), phosphate-buffered saline (PBS), trypsin-EDTA solution, penicillin and streptomycin were purchased from Gibco; Thermo Fisher Scientific, Inc. 3-(4,5-Dimethythiazol-2-yl)-2,5-diphenyltetrazolium bromide (MTT), the Annexin V-fluorescein isothiocyanate (FITC)/propidiumiodide(PI) kit, 3,3'-dihexyloxacarbocyanine iodide ( $\mathrm{DiOC}_{6}$ ), dichlorodihydrofluorescein diacetate (DCFH-DA), dihydroethidium (DHE), DMSO, epidermal growth factor (EGF), cholera toxin, hydrocortisone and insulin were purchased from Sigma-Aldrich; Merck KGaA. Caspase 9 (LEHD-para-nitroaniline; LEHD-p-NA), caspase 8 (IETD- $p$-NA) and caspase 3 (DEVD- $p$-NA) activity colorimetric assay kits were obtained from Invitrogen; Thermo Fisher Scientific, Inc. The primers and RevertAid First Strand cDNA Synthesis kit were obtained from Thermo Fisher Scientific, Inc. The RNA Prep Pure kit was purchased from Tiangen Biotech Co., Ltd and the SensiFAST SYBR Lo-ROX kit was purchased from Bioline; Meridian Biosciences. The mitochondria/cytosol fractionation kit, primary antibodies against NOXA (ab13654), BAX (ab32503), Bcl-xL (ab2568), cytochrome $c$ (ab6400), 
$\beta$-actin (ab8227), COX-4 (ab16056) and Rip3 (ab56164), rabbit HRP-conjugated secondary antibody (ab97051), and mouse HRP-conjugated secondary antibody (ab97046) were purchased from Abcam. The ECL Prime Western Blotting System was purchased from GE Healthcare.

Phytochemical screening. The ethyl acetate crude extracts were screened for the presence of bioactive chemical constituents, including alkaloids, flavonoids, phytosterols, terpenoids, saponins, phenols and tannins using the standard methods outlined below (39-41). The results were reported as -, absent; + , present; ++ abundant.

Detection of alkaloids. Dry extracts (50 mg each) were dissolved in $1 \mathrm{ml}$ of $2 \%$ hydrochloric acid and filtered using Whatman filter paper no. 1 . The filtrates were treated with $100 \mu \mathrm{l}$ potassium mercuric iodide, and a yellow-colored precipitate indicated the presence of alkaloids.

Detection of flavonoids. Dry extracts (100 mg each) were dissolved in $4 \mathrm{ml}$ ethyl acetate and filtered using Whatman filter paper no. 1 . The filtrates were treated with $200 \mu \mathrm{l}$ sodium hydroxide solution followed by $1 \%$ sulfuric acid. The formation of an intense yellow color became colorless when $1 \%$ sulfuric acid was added, which indicated the presence of flavonoids.

Detection of phytosterols. Dry extracts (50 mg each) were dissolved in $1 \mathrm{ml}$ chloroform and filtered using Whatman filter paper no. 1 . The filtrates were treated with $100 \mu \mathrm{l}$ acetic anhydride, boiled at $90-100^{\circ} \mathrm{C}$ and then subsequently cooled at room temperature. Then, $1 \mathrm{ml} 95 \%$ sulfuric acid was added and the formation of a brown ring at the junction indicated the presence of phytosterols.

Detection of triterpenoids. Dry extracts (50 mg each) were dissolved in $1 \mathrm{ml}$ chloroform and filtered using Whatman filter paper no. 1 . The filtrates were treated with $100 \mu 195 \%$ sulfuric acid, gently shaken and then allowed to stand for $5 \mathrm{~min}$. Formation of a golden-yellow color indicated the presence of triterpenoids.

Detection of diterpenes. Dry extracts (50 mg each) were dissolved in $1 \mathrm{ml}$ distilled water and treated with $200 \mu \mathrm{l}$ copper acetate solution. The Appearance of an emerald green color indicated the presence of diterpenes.

Detection of saponins. Dry extracts (50 mg each) were dissolved in $20 \mathrm{ml}$ distilled water and shaken in a graduated cylinder for $15 \mathrm{~min}$. The formation of a 1-cm layer of foam indicated the presence of saponins.

Detection of phenols. Dry extracts (50 mg each) were dissolved in $1 \mathrm{ml}$ distilled water and treated with $100 \mu \mathrm{l} 2 \%$ ferric chloride. The formation of a bluish-green or black coloration confirmed the presence of phenols.

Detection of tannins. Dry extracts (50 mg each) were boiled at $90-100^{\circ} \mathrm{C}$ in $1 \mathrm{ml}$ distilled water for $5 \mathrm{~min}$ and then filtered using Whatman filter paper no. $1 ; 100 \mu 10.1 \%$ ferric chloride was added to the filtrates, and the appearance of a brownish-green or a blue-black color indicated the presence of tannins.
Gas chromatography-mass spectrometry $(G C-M S)$ analysis. BEA and CEA were subjected to GC-MS detection, which was performed using a GC 7890A attached to a MSD 5975C (Agilent Technologies, Inc.). The chromatograph was fitted with a HP5-MS capillary column (30 m x $0.25 \mathrm{~mm}, 0.25-\mu \mathrm{m}$ film thickness) using a temperature program initially set to $100-150^{\circ} \mathrm{C}$, at a rate of $3^{\circ} \mathrm{C} / \mathrm{min}$ for $16.67 \mathrm{~min}$. Then, the temperature was raised to $300^{\circ} \mathrm{C}$ at a rate of $5^{\circ} \mathrm{C} / \mathrm{min}$, for $30 \mathrm{~min}$, and then held at $300^{\circ} \mathrm{C}$ for $10 \mathrm{~min}$; the total run time was $56.67 \mathrm{~min}$. The injector was set at $280^{\circ} \mathrm{C}$ and the injection volume was at $1.0 \mu \mathrm{l}$ in the split mode (2:1). The flow speed of helium, the carrier gas, was $1 \mathrm{ml} / \mathrm{min}$. The mass spectra were scanned from $\mathrm{m} / \mathrm{z} 50-550$, and the electron impact ionization energy was set at $70 \mathrm{eV}$. Identification of the components was based on the comparison of their mass spectra and retention times with those of the standard authentic compounds. This was accomplished using Agilent ChemStation Integrator (Agilent Technologies, Inc.) software computer matching using the National Institute Standard and Technology Library (nist.gov/nist-research-library).

Cell culture. The human MDA-MB-231 breast cancer cell line was obtained from the American Type Culture Collection (ATCC). The cells were cultured in DMEM and supplemented with $10 \% \mathrm{FBS}, 100 \mathrm{U} / \mathrm{ml}$ penicillin and $100 \mu \mathrm{g} / \mathrm{ml}$ streptomycin. The human MCF10A mammary epithelial cell line was obtained from the ATCC and cultured in DMEM/Ham's F-12 supplemented with 5\% HS, $20 \mathrm{ng} / \mathrm{ml} \mathrm{EGF,} 0.5 \mathrm{mg} / \mathrm{ml}$ hydrocortisone, $100 \mathrm{ng} / \mathrm{ml}$ cholera toxin, $10 \mu \mathrm{g} / \mathrm{ml}$ insulin, $50 \mathrm{U} / \mathrm{ml}$ penicillin and $50 \mu \mathrm{g} / \mathrm{ml}$ streptomycin. Both cell lines were cultured at $37^{\circ} \mathrm{C}$ in a $5 \% \mathrm{CO}_{2}$ atmosphere.

Cytotoxicity determination by MTT assay. MDA-MB-231 and MCF10A cells were seeded into 96-well plates at $5 \times 10^{4}$ cells $/ \mathrm{ml}$ and treated with BEA, CEA or Doxorubicin at various concentrations. The cells were then incubated for $24 \mathrm{~h}$ at $37^{\circ} \mathrm{C}$ before detecting cell viability using the MTT method, as previously described (42). Briefly, MTT reagent was added to the cells, which were then incubated for $4 \mathrm{~h}$ at $37^{\circ} \mathrm{C}$. The formazan crystals were dissolved using DMSO and the optical density was measured at $540 \mathrm{~nm}$ (with a reference wavelength of $630 \mathrm{~nm}$ ). The results were expressed as a percentage of cell viability and were compared with untreated control cells. The inhibitory concentration (IC) $)_{10}, \mathrm{IC}_{20}$ and $\mathrm{IC}_{50}$ values were calculated in the presence of each of the extracts.

Apoptosis investigation using annexin V-FITC and PI staining. MDA-MB-231 cells were treated with BEA and $\mathrm{CEA}$ at $\mathrm{IC}_{10}, \mathrm{IC}_{20}$ and $\mathrm{IC}_{50}$ for $24 \mathrm{~h}$, at $37^{\circ} \mathrm{C}$, and then stained with annexin V-FITC and PI for $15 \mathrm{~min}$. The percentages of apoptotic cells were quantified by annexin V-FITC positive staining (43), detected using the BD FACSAria ${ }^{\mathrm{TM}}$ III Cell Sorter flow cytometer (BD Biosciences) and then analyzed with BD FACSDiva software version 7.0 (BD Biosciences). The treated cell results were compared with untreated control cells.

Assessment of mitochondrial transmembrane depolarization. To detect changes in mitochondrial transmembrane potential $(\triangle \Psi \mathrm{m}), \mathrm{MDA}-\mathrm{MB}-231$ cells were treated with BEA and CEA for $24 \mathrm{~h}$ at $37^{\circ} \mathrm{C}$. BEA and CEA-treated and untreated control 
cells were stained using $\mathrm{DiOC}_{6}$ at a final concentration of $40 \mathrm{nM}$ for $15 \mathrm{~min}$ at $37^{\circ} \mathrm{C}$. Then, the cells were washed and analyzed using a FACSCAtia ${ }^{\mathrm{TM}}$ III Cell Sorter flow cytometer (BD Biosciences) (44).

Measurement of reactive oxygen species (ROS) generation. The levels of intracellular ROS were measured, and included those of superoxide anion, hydrogen peroxide and peroxide radicals; two intracellular redox-sensitive fluorescent dyes, DHE and DCFH-DA, were used according to previously described methods (45). Briefly, after the MDA-MB-231 cells were treated with BEA and CEA at $\mathrm{IC}_{10}, \mathrm{IC}_{20}$ and $\mathrm{IC}_{50}$ for $12 \mathrm{~h}$, the cells were stained with DHE and DCFH-DA at a final concentration of $2 \mu \mathrm{M}$ for $30 \mathrm{~min}$ at $37^{\circ} \mathrm{C}$. Fluorescence intensity was measured using a fluorescence microplate reader (BioTek Instruments, Inc.) at $535 \mathrm{~nm}$ excitation and $635 \mathrm{~nm}$ emission wavelengths for DHE, and $485 \mathrm{~nm}$ excitation and $525 \mathrm{~nm}$ emission wavelengths for DCFH-DA $(46,47)$. The results were compared between treated and untreated cells. $3 \% \mathrm{H}_{2} \mathrm{O}_{2}$ was used as the positive control for DCFH-DA staining, whereas $\mathrm{FeSO}_{4}$ was used as the positive control for DHE staining.

Determination of caspase activities. Caspase 3, 8 and 9 activities were measured in cellular protein extracts using colorimetric assay kits. Following treatment with BEA and CEA at $\mathrm{IC}_{10}, \mathrm{IC}_{20}$ and $\mathrm{IC}_{50}$, the MDA-MB-231 cells were lysed and the total protein was quantified using a Bradford protein assay. Caspase activity was detected using the specific substrates DEVD- $p$-NA, IETD- $p$-NA and LEHD- $p$-NA for caspase 3,8 and 9 , respectively. The absorbance was then determined at $405 \mathrm{~nm}$ using a microplate reader (BioTek Instruments, Inc.) (44). The results were compared between treated and untreated cells.

Analysis of gene expression levels by reverse transcriptionquantitative (RT-qPCR). After treatment of the MDA-MB-231 cells with BEA and CEA at $\mathrm{IC}_{10}, \mathrm{IC}_{20}$ and $\mathrm{IC}_{50}$ (for $24 \mathrm{~h}$ at $37^{\circ} \mathrm{C}$ ), the total RNA was extracted using the Tiangen RNA Prep Pure kit, and then reverse transcribed into cDNA using the RevertAid First Strand cDNA Synthesis kit. mRNA expression levels of NOXA, BAX and Bcl-xL were quantified using the SensiFAST SYBR Lo-ROX kit (Bioline; Meridian Biosciences) and the 7500 Fast Real-time PCR system (Applied Biosystems; Thermo Fisher Scientific, Inc.). The relative gene expression levels were analyzed using the $2^{-\Delta \Delta C q}$ method (48) with GAPDH as the housekeeping gene. The primers for NOXA, BAX, Bcl-xL and GAPDH were as follows: NOXA, forward 5'GCTGGAAGTCGAGTGTGCTA3' and reverse 5'CCTGAGCAGAAGAGTTTGGA3'; BAX, forward 5'AGC AGATCATGAAGACAGGGG3' and reverse 5'ACACTCGCT CAGCTTCTTGG3'; Bcl-xL, forward 5'GCTGGGACACTTT TGTGGAT3' and reverse 5'TGTCTGGTCACTTCCGAC TG3'; and GAPDH, forward 5'TGCACCACCAACTGCTTA GC3' and reverse 5'GGCATGGACTGTGGTCATGAG3'. The primers were designed and selected using the Primer-BLAST tool (ncbi.nlm.nih.gov/tools/primer-blast/) $(48,49)$.

Western blotting. To determine the protein expression levels in MDA-MB-231 cells, the cells were seeded into culture dishes and treated with BEA or CEA for $24 \mathrm{~h}$ at $\mathrm{IC}_{10}, \mathrm{IC}_{20}$ and
Table I. Phytochemical screening test of BEA and CEA.

\begin{tabular}{lcc}
\hline Phytoconstituent & BEA & CEA \\
\hline Alkaloids & + & + \\
Flavonoids & ++ & ++ \\
Phytosterols & ++ & + \\
Triterpenoids & ++ & + \\
Diterpenoids & - & ++ \\
Saponins & + & - \\
Phenols & ++ & - \\
Tannins & ++ & + \\
\hline
\end{tabular}

BEA, Bridelia ovata; CEA, Croton oblongifolius; -, absent; +, present; ++ abundant.

$\mathrm{IC}_{50}$; untreated MDA-MB-231 cells were used as the control. Following treatment, the cells were harvested and lysed using RIPA lysis buffer supplemented with a protease inhibitor. The mitochondria/cytosol fractionation kit was used to extract cytosolic and mitochondrial proteins per the manufacturer's protocol. Protein concentrations were measured using a Bradford protein assay (50), and protein expression levels were assessed using western blot analysis (51). A total of $20 \mu \mathrm{g}$ (for NOXA, BAX, Bcl-xL, Rip3, COX-IV and $\beta$-actin) and $80 \mu \mathrm{g}$ (for cytochrome $c$ ) total protein per lane was loaded onto a $12 \%$ gel, resolved using SDS-PAGE and subsequently transferred onto nitrocellulose membranes. The membranes were blocked with $5 \%$ skim milk at room temperature for $1 \mathrm{~h}$, and then incubated with primary antibodies against NOXA, BAX, Bcl-xL, cytochrome $c$, Rip3 and COX-IV $(1: 1,000)$ at $4^{\circ} \mathrm{C}$ overnight $(\beta$-actin was used at 1:20,000). Next, the membranes were washed and incubated with HRP-conjugated secondary antibodies $(1: 5,000)$ for $2 \mathrm{~h}$ at room temperature. For visualization, an ECL Prime Western Blotting System was used and antibody-specific chemiluminescent bands were detected using an Omega Lum W Imager (Gel Company, Inc.). Quantification of the band density was conducted using ImageJ 1.52p (National Institutes of Health). $\beta$-actin and COX-IV were used as the loading controls for whole cell/cytosolic and mitochondrial proteins, respectively.

Statistical analysis. The data are presented as the mean \pm standard deviation (SD), calculated from three independent experiments (unless otherwise stated). The statistical differences between multiple-group comparisons were determined using the Kruskal-Wallis test and Dunn's multiple comparisons post-hoc test, and $\mathrm{P}<0.05$ was considered to indicate a statistically significant difference. All statistical analyses were performed using SPSS version 22.0. (IBM Corp.).

\section{Results}

Percentage yield and phytochemical screening of BEA and $C E A$. The percentage yields of BEA and CEA were 0.31 and $0.95 \%$, respectively. For phytochemical screening of the extracts, standard methods were applied (41). BEA contained alkaloids, flavonoids, phytosterols, triterpenoids, saponins, phenols and tannins with an absence of diterpenoids. The 
Table II. Phytochemical analyses and identified compound profiles with retention time, name and percentage of total in BEA and CEA treatment.

\section{A, BEA}

\begin{tabular}{|c|c|c|}
\hline Retention time (min) & Compounds & $\%$ of total \\
\hline 8.948 & 2-methoxy-4-vinylphenol & 1.62 \\
\hline 10.960 & 1,2,3-benzenetriol & 7.70 \\
\hline 11.618 & Benzaldehyde, 4-hydroxy-3-methoxy- & 1.15 \\
\hline 16.653 & Benzene, 1,2,3-trimethoxy-5-(2-propenyl)- & 0.43 \\
\hline 20.070 & Benzaldehyde, 4-hydroxy-3,5-dimethoxy- & 0.43 \\
\hline 23.150 & Tetradecanoic acid & 0.88 \\
\hline 28.006 & Palmitic acid & 10.28 \\
\hline 30.986 & Linoleic acid & 0.25 \\
\hline 31.429 & Oleic acid & 7.92 \\
\hline 31.733 & Stearic acid & 0.63 \\
\hline 37.568 & Di-n-octylphthalate & 0.72 \\
\hline 42.957 & 1-Nonadecene & 0.69 \\
\hline 45.674 & 1-Hexacosanol & 2.59 \\
\hline 45.862 & $\alpha$-Tocopherol & 1.03 \\
\hline 46.593 & Cirsilineol & 0.83 \\
\hline 47.059 & Campesterol & 4.18 \\
\hline 47.477 & Stigmasterol & 7.74 \\
\hline 48.060 & 24-n-propylidenecholesterol & 1.06 \\
\hline 48.433 & Stigmast-5-en-3-ol & 19.55 \\
\hline 48.558 & Fucosterol & 1.09 \\
\hline 49.689 & Stigmasta-3,5-dien-7-one & 1.18 \\
\hline 50.367 & Stigmast-4-en-3-one & 0.92 \\
\hline 50.522 & 9,19-Cyclolanostan-3-ol, 24-methylene-, (3.beta.)- & 0.80 \\
\hline 52.247 & Friedelan-3-one & 20.09 \\
\hline
\end{tabular}

\section{B, CEA}

\begin{tabular}{llr}
\hline Retention time $(\mathrm{min})$ & & \multicolumn{1}{c}{ Compounds } \\
\hline 5.589 & Benzoic acid & 4.54 \\
27.688 & Palmitic acid & 2.38 \\
29.082 & Biformen & 1.15 \\
29.210 & (-)-Kaur-16-ene & 2.00 \\
33.331 & 4-Hydroxy-3,5,4'-trimethoxystilbene \\
36.634 & Kaur-16-en-18-oic acid \\
36.794 & 9-Isopropylidene-5,6,7,8-tetramethyl-1,4-dihydro-1,4-methano-naphthalene \\
43.416 & Aflatoxin G1 \\
47.055 & Campesterol \\
47.413 & Stigmasterol & 3.25 \\
48.286 & Stigmast-5-en-3-ol & 2.66 \\
49.673 & Stigmasta-3,5-dien-7-one & 2.54 \\
& & 2.06 \\
\hline
\end{tabular}

BEA, Bridelia ovata; CEA, Croton oblongifolius.

CEA results revealed the presence of alkaloids, flavonoids, phytosterols, triterpenoids, diterpenoids and tannins with an absence of saponins and phenols. The results of these qualitative phytochemical analyses are presented in Table I.
Identification of BEA and CEA compounds using GC-MS. The characterization of BEA and CEA extracts are presented in Table II. A total of 24 BEA compounds and 12 CEA compounds were identified. Their respective retention times and percentages 
A GC/MS: B. ovata

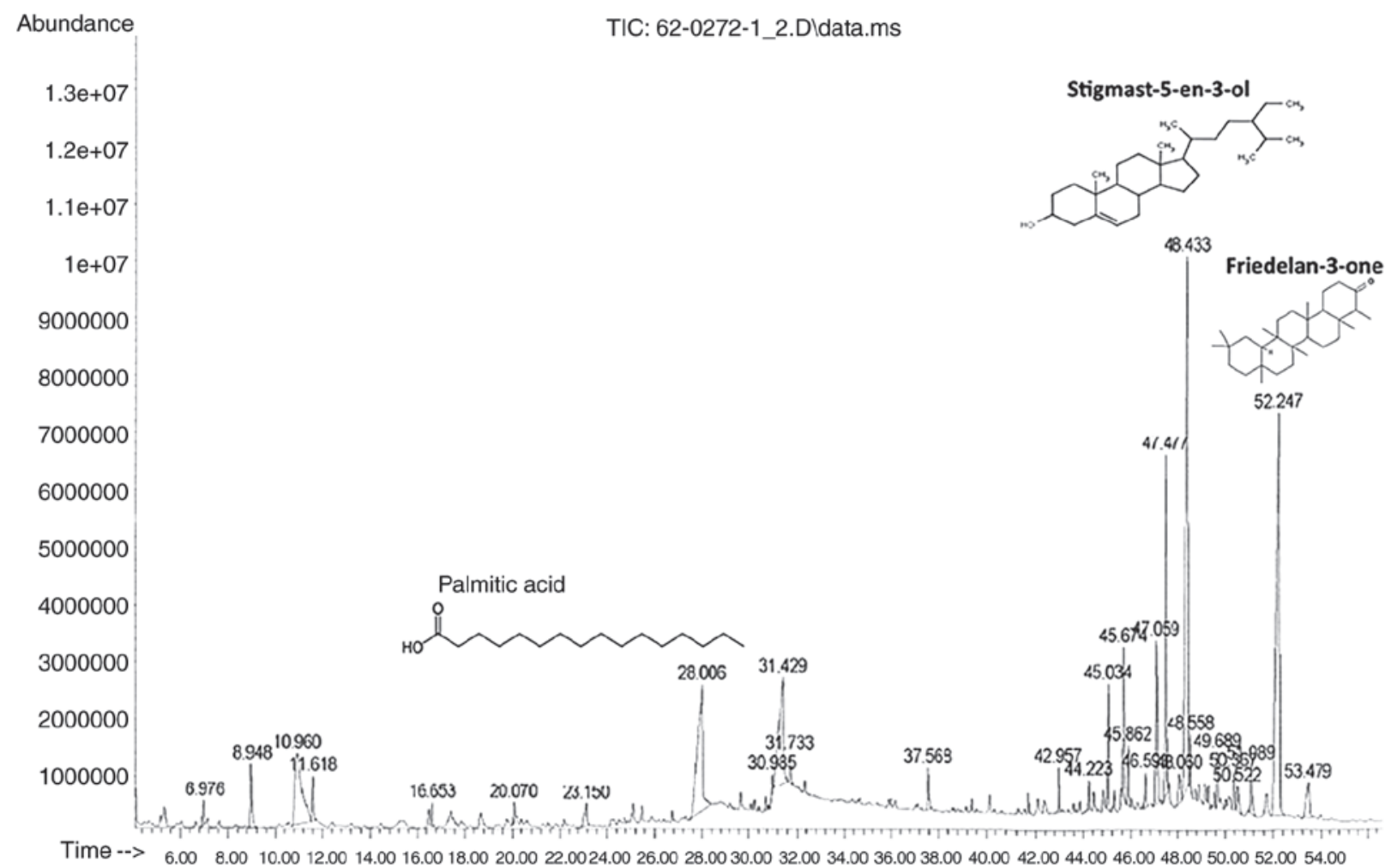

\section{B GC/MS: C. oblongifolius}

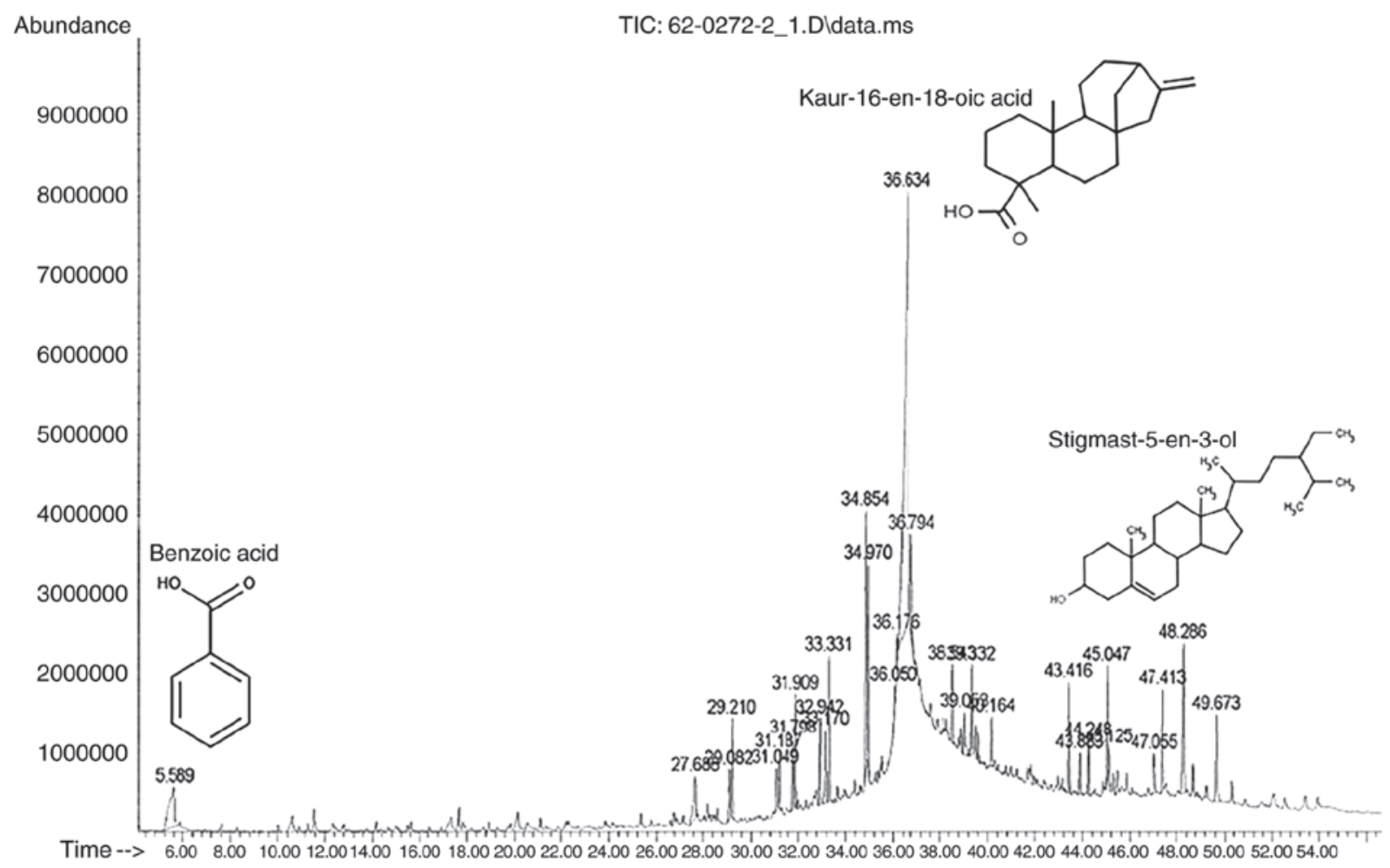

Figure 1. GC-MS chromatographs of BEA and CEA. Chromatograms of (A) BEA and (B) CEA show the retention time on the x-axis and the intensity (absorbance) of the signal at the y-axis. The chemical structures of the three most abundant compounds identified in each extract are presented. GC-MS, gas chromatography-mass spectrometry BEA, Bridelia ovata; CEA, Croton oblongifolius.

of the total are stated. The GC-MS chromatogram and structures of the 3 major identified compounds of each extract are presented in Fig. 1. The GC-MS results show that the primary phytoconstituent of BEA is friedelan-3-one (20.1\%) and that the primary active compound of CEA is kaur-16-en-18-oic acid (36.1\%). 
Table III. $\mathrm{IC}_{10}, \mathrm{IC}_{20}$ and $\mathrm{IC}_{50}$ values in MDA-MB-231 cells and $\mathrm{IC}_{50}$ in MCF10A cells treated with BEA, CEA and doxorubicin.

A, MDA-MA-231

\begin{tabular}{lccr}
\hline Concentration & $\mathrm{BEA} \pm \mathrm{SD}(\mu \mathrm{g} / \mathrm{ml})$ & $\mathrm{CEA} \pm \mathrm{SD}(\mu \mathrm{g} / \mathrm{ml})$ & Doxorubicin $\pm \mathrm{SD}(\mu \mathrm{M})$ \\
\hline $\mathrm{IC}_{10}$ & $7.6 \pm 1.9$ & $3.9 \pm 0.7$ & - \\
$\mathrm{IC}_{20}$ & $14.4 \pm 2.4$ & $8.5 \pm 1.3$ & - \\
$\mathrm{IC}_{50}$ & $40.0 \pm 3.6$ & $29.7 \pm 3.4$ & $4.1 \pm 0.8$ \\
\hline
\end{tabular}

\section{$\mathrm{B}, \mathrm{MCF} 10 \mathrm{~A}$}

\begin{tabular}{lccc}
\hline Concentration & $\mathrm{BEA} \pm \mathrm{SD}, \mu \mathrm{g} / \mathrm{ml}$ & $\mathrm{CEA} \pm \mathrm{SD}, \mu \mathrm{g} / \mathrm{ml}$ & Doxorubicin $\pm \mathrm{SD}(\mu \mathrm{M})$ \\
\hline $\mathrm{IC}_{50}$ & $393.8 \pm 4.3$ & $82.0 \pm 4.3$ & $8.7 \pm 0.8$ \\
$\mathrm{SI}^{\mathrm{a}}$ & 9.8 & 2.8 & 2.1
\end{tabular}

${ }^{a}$ SI values of each agent, which are ratio of $\mathrm{IC}_{50}$ of MCF10A/MDA-MB-231 cells. IC, inhibitory concentration; SI, selectivity index; BEA, Bridelia ovata; CEA, Croton oblongifolius; SD, standard deviation.
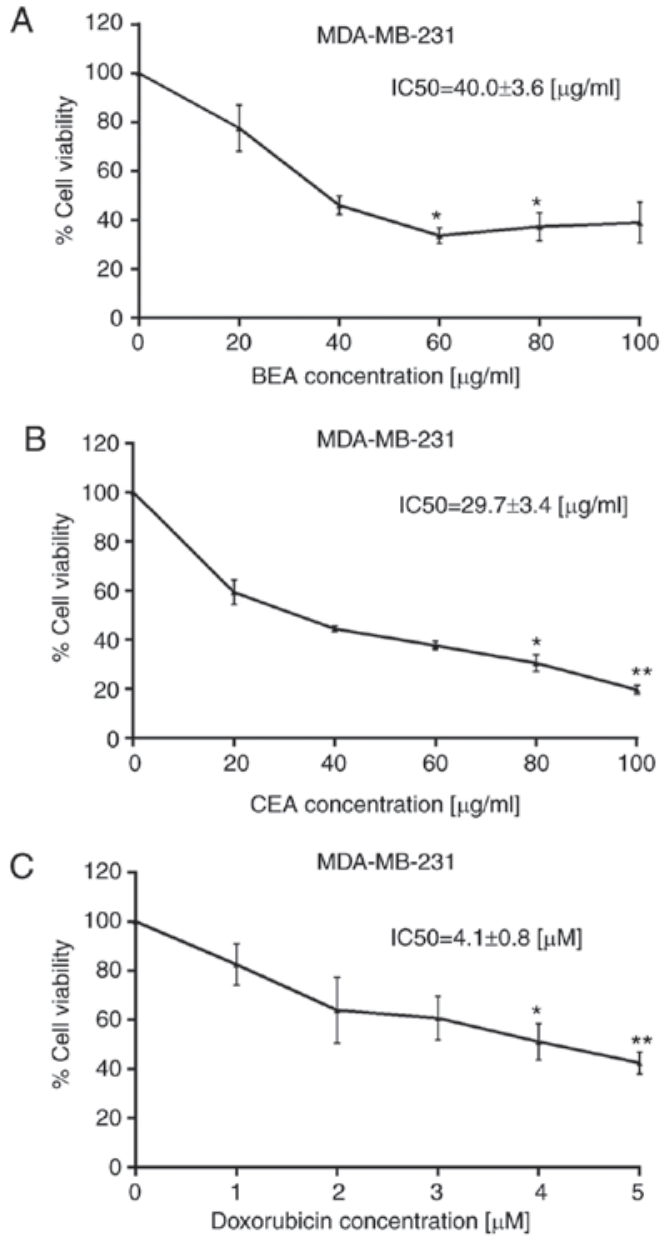
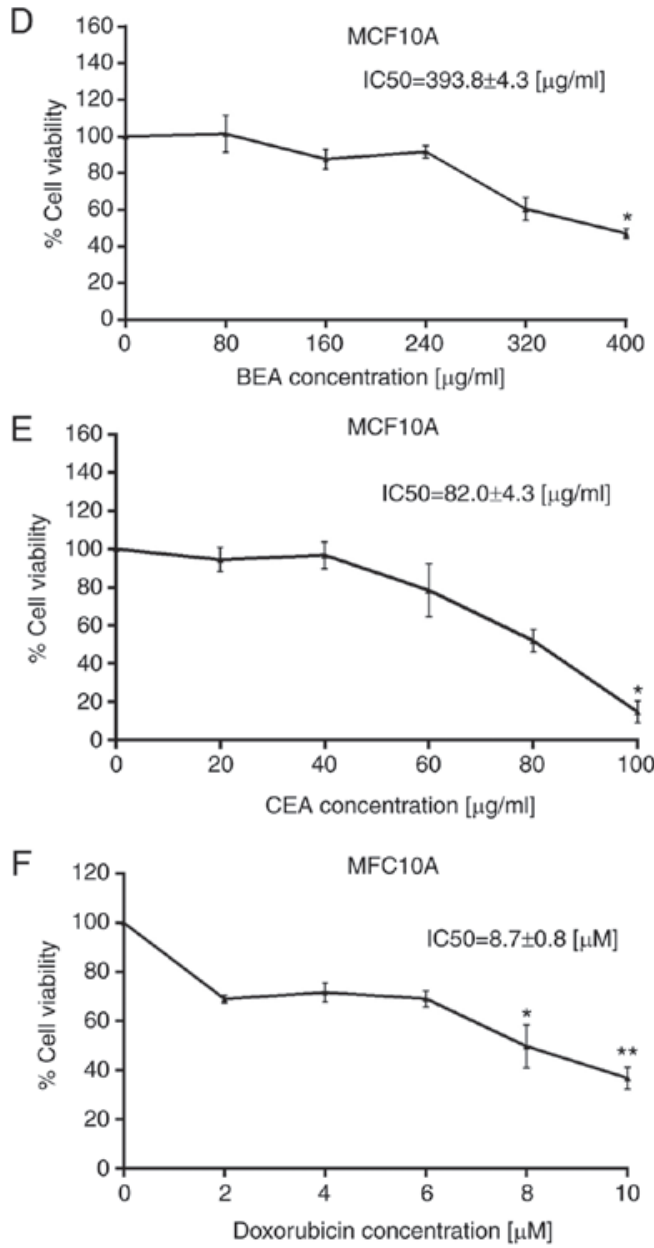

Figure 2. Cytotoxic effects of BEA, CEA and doxorubicin in MDA-MB-231 and MCF10A cells. MDA-MB-231 cells treated with (A) BEA, (B) CEA and (C) doxorubicin at different concentrations. MCF10A cells treated with (D) BEA, (E) CEA and (F) doxorubicin at different concentrations. "P<0.05 and ${ }^{* *} \mathrm{P}<0.01$ vs. control. BEA, Bridelia ovata; CEA, Croton oblongifolius; IC, inhibitory concentration.

Cytotoxicity of BEA and CEA in MDA-MB-231 and MCF10A cells. BEA and CEA exhibited a cytotoxic effect on MDA-MB-231 and MCF10A cells. The percentage of cell viability was calculated compared with the untreated control 


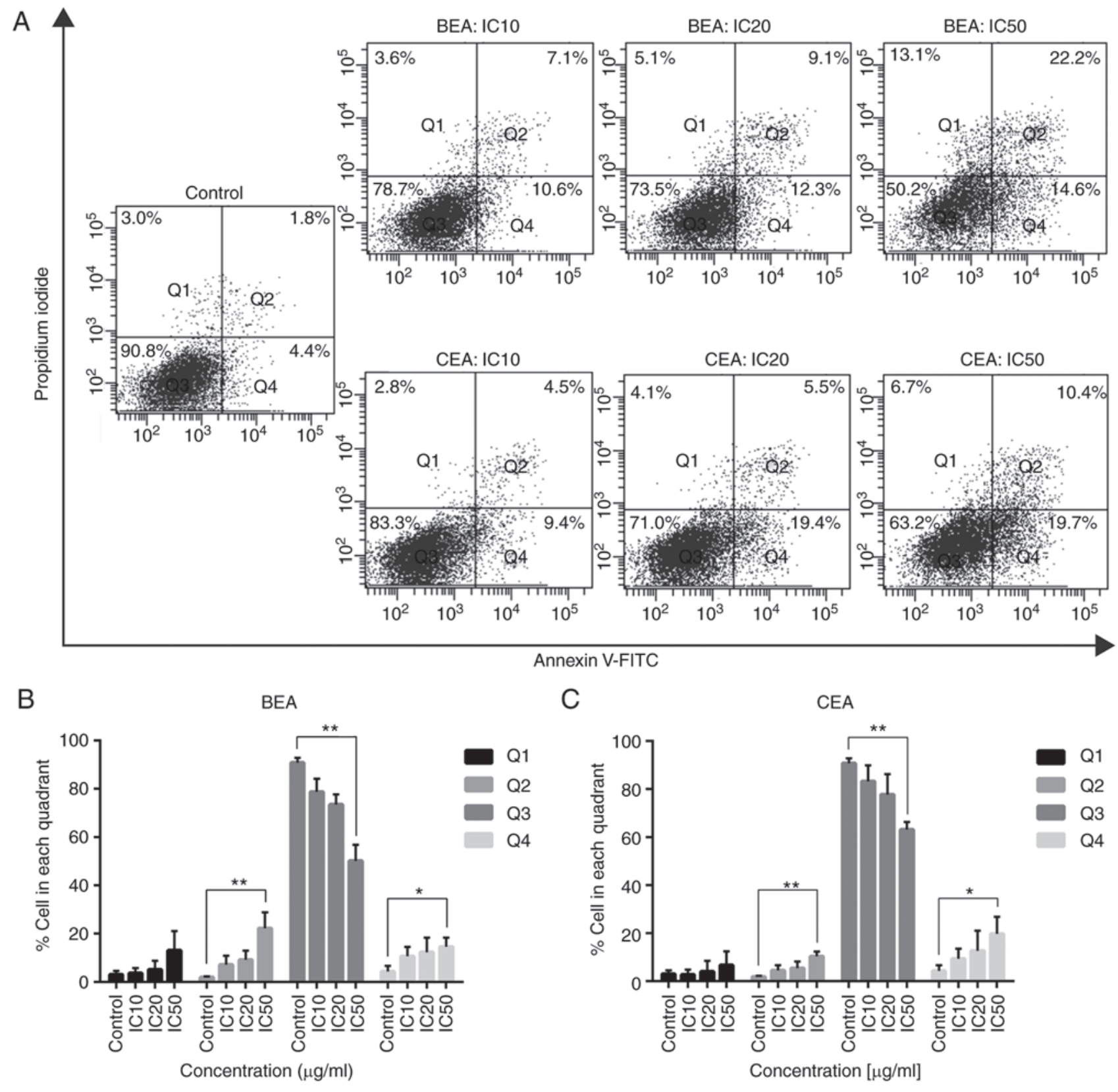

Figure 3. Induction of apoptosis in MDA-MB-231 cells by BEA and CEA. (A) Dot plots represent the cell population in each quadrant, which shows positive and/or negative Annexin V-FITC (x-axis) and PI (y-axis) staining. (B and C) Bar graphs showing the percentages of cells in each quadrant, including $\mathrm{Q} 1$ = necrosis/necroptosis, $\mathrm{Q} 2=$ late apoptosis/necroptosis, $\mathrm{Q} 3=$ living cells and $\mathrm{Q} 4=$ early apoptosis. ${ }^{*} \mathrm{P}<0.05$ and ${ }^{* *} \mathrm{P}<0.01$ vs. control. BEA, Bridelia ovata; CEA, Croton oblongifolius; IC, inhibitory concentration.

cells (100\% cell viability). The $\mathrm{IC}_{10}, \mathrm{IC}_{20}, \mathrm{IC}_{50}$ and selectivity index (SI) of BEA, CEA and doxorubicin for both cell types were calculated (Table III). BEA and CEA significantly decreased MDA-MB-231 cell viability in a dose-dependent manner (Fig. 2A and B). The $\mathrm{IC}_{50}$ of BEA and CEA were $40.0 \pm 3.6$ and $29.7 \pm 3.4 \mu \mathrm{g} / \mathrm{ml}$, respectively. However, BEA and CEA also decreased the viability of MCF10A cells (Fig. 2D and E) but at higher concentrations compared with their effect on MDA-MB-231 cells. The results are in accordance with the selectivity index criteria: $\mathrm{SI} \geq 3=$ high selectivity and $\mathrm{SI}<3=$ less selectivity $(52,53)$. Therefore, BEA possessed a high SI (9.84), whereas CEA had less selectivity (2.76). Doxorubicin, the conventional chemotherapeutic drug used for breast cancer (54), was used to treat both cell types
(Fig. 2C and F). The $\mathrm{IC}_{50}$ of doxorubicin in MCF10A cells was higher than that in MDA-MB-231 cells and the SI of both BEA and CEA were higher than doxorubicin (2.13). This suggests that these two extracts have more selectivity towards breast cancer cells than noncancerous cells, which may relate to a reduction in adverse effects.

Mode of cell death induced by BEA and CEA in MDA-MB-231 cells. Annexin V-FITC/PI staining was employed to determine the mode of cell death in MDA-MB-231 cells after treatment with both extracts. Dot plot analyses show the percentage of cells in each quadrant (Fig. 3A). The percentages of cells in early (Q4) and late apoptosis (Q2) were significantly increased compared with the control, whereas 


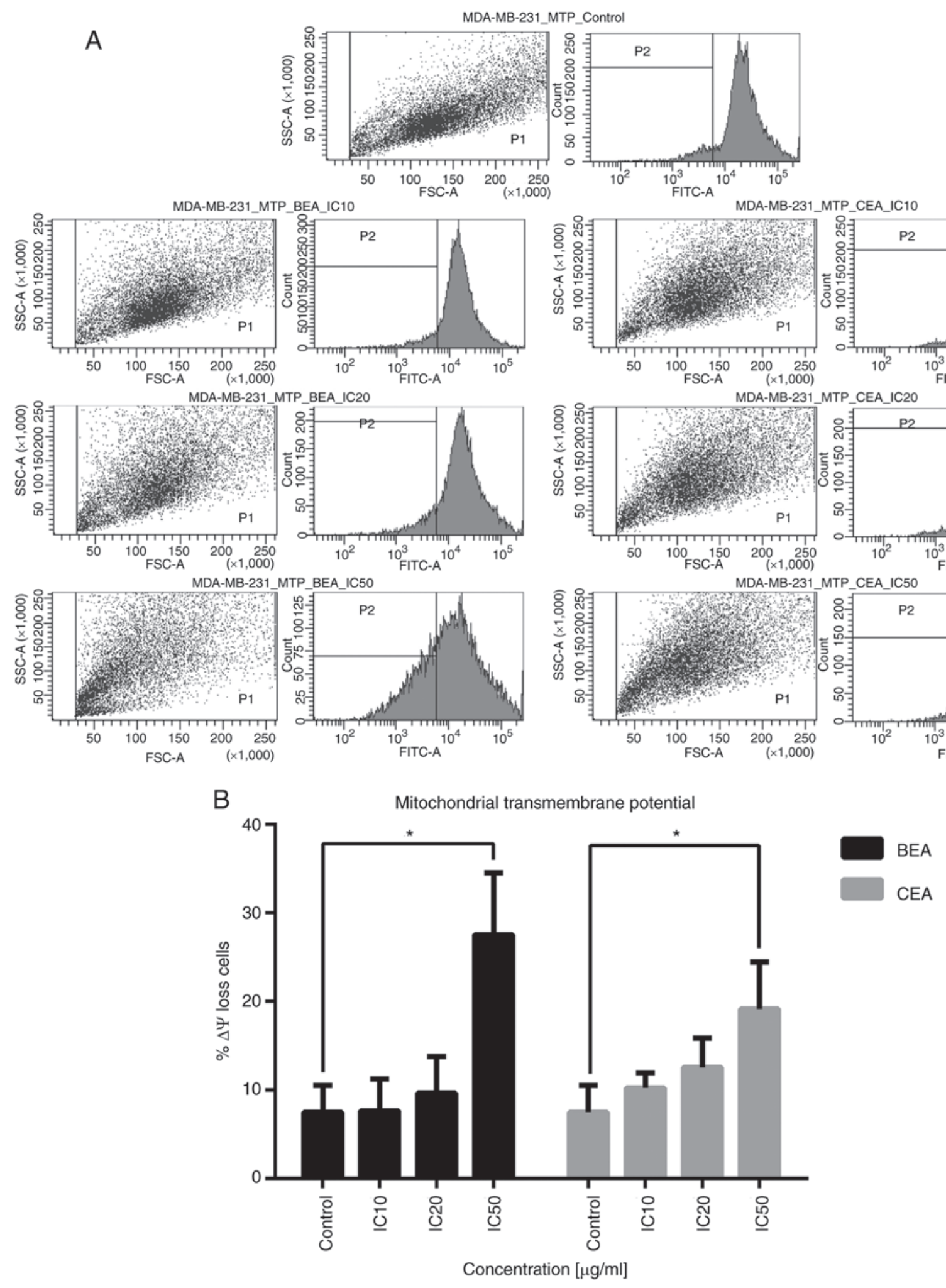

Figure 4. Reduction of mitochondrial transmembrane potential $(\Delta \Psi \mathrm{m})$ in MDA-MB-231 cells induced by BEA and CEA. MDA-MB-231 cells were incubated with BEA and CEA at the indicated IC. A decrease of the $\mathrm{DiOC}_{6}$ indicates the percentage of cells with $\triangle \Psi \mathrm{m}$ loss. (A) Histogram of DiOC 6 shows the number of cells at each $\mathrm{DiOC}_{6}$ intensity. The $\mathrm{x}$-axis represents the $\mathrm{DiOC}_{6}$ intensity and the $\mathrm{y}$-axis indicates the cell count within the corresponding fluorescence intensity. (B) Bar graph showing the percentage of cells with $\Delta \Psi \mathrm{m}$ loss on the y-axis and extract concentrations on the $\mathrm{x}$-axis. ${ }^{*} \mathrm{P}<0.05$ vs. control. BEA, Bridelia ovata; CEA, Croton oblongifolius; IC, inhibitory concentration.

the percentage of living cells (Q3) was significantly decreased after BEA treatment at $\mathrm{IC}_{50}$ concentration compared with the control; similar results were observed following CEA treatment (Fig. 3B and C). However, the number of necrotic cells in Q1 was increased, but not significantly compared with the control cells; supplementary data demonstrates that necroptosis marker protein RIP3 did not change the expression levels following BEA and BEA treatment (Fig. S1). 
A
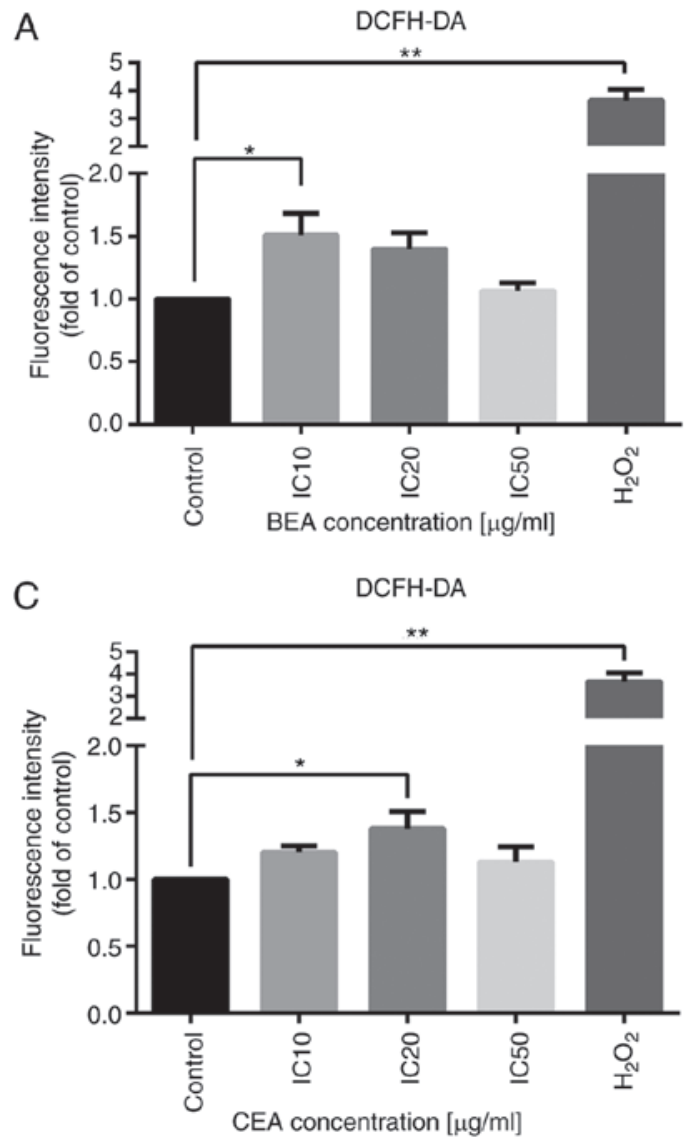
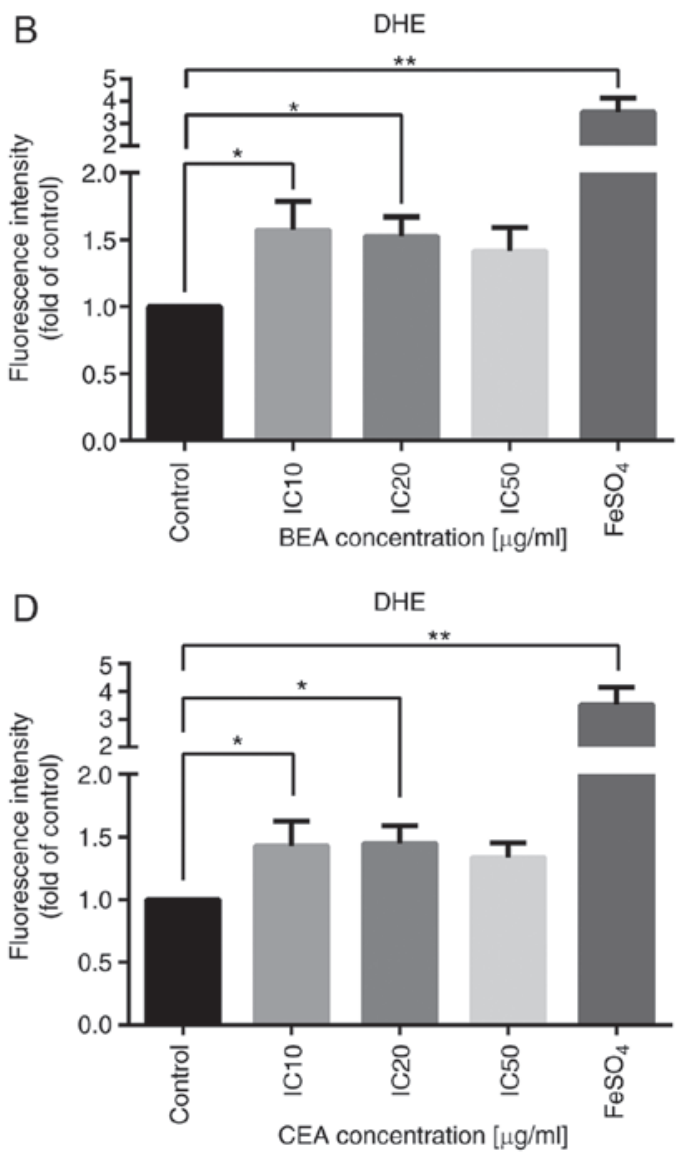

Figure 5. Induction of intracellular ROS generation by BEA and CEA. The fluorescence intensities of the DCFH-DA and DHE staining probes are shown on the $\mathrm{y}$-axis as the fold of the control. MDA-MB-231 cells were treated with (A and B) BEA and (C and D) with CEA. The cells were stained with DCFH-DA using $3 \% \mathrm{H}_{2} \mathrm{O}_{2}$ as the positive control, and with $\mathrm{DHE}$ using $\mathrm{FeSO}_{4}$ as the positive control. ${ }^{*} \mathrm{P}<0.05$ and ${ }^{* *} \mathrm{P}<0.01$ vs. the respective control. BEA, Bridelia ovata; CEA, Croton oblongifolius; IC, inhibitory concentration.

Therefore, BEA and CEA induced MDA-MB-231 cell death via the apoptosis pathway.

Reduction of $\Delta \Psi m$ and intracellular ROS generation. Mitochondrial dysfunction is a key event in the intrinsic apoptosis pathway, and depolarization of $\Delta \Psi \mathrm{m}$, which occurs during apoptosis (55), was measured to determine the level of mitochondrial disruption induced by BEA and CEA. The percentage of MDA-MB-231 cells with $\Delta \Psi \mathrm{m}$ loss was significantly increased after treatment with BEA and $\mathrm{CEA}$ at $\mathrm{IC}_{50}$ (Fig. 4B). The reduction of $\Delta \Psi \mathrm{m}$ indicates mitochondrial dysfunction. The intracellular ROS were measured using two fluorescent dyes. DCFH-DA is widely used probe for detecting $\mathrm{H}_{2} \mathrm{O}_{2}$ and oxidative stress and DHE is another used probe for detecting intracellular $\mathrm{O}^{\bullet-2}(56)$. The fluorescent intensity of both DCFH-DA and DHE probes were increased following BEA and CEA treatment, compared with the untreated control (Fig. 5), thus $\mathrm{H}_{2} \mathrm{O}_{2}$ and $\mathrm{O}^{\bullet-2}$ were generated. However, the level of ROS generation did not increase in a dose-dependent manner (though they were significantly increased). This indicates that BEA and CEA induced oxidative stress and mitochondrial dysfunction during MDA-MB-231 cell apoptosis.

Effect of BEA and CEA on caspase activity. In MDA-MB-231 cells, caspase 3 and 9 activities were significantly increased following treatment with BEA and CEA (Fig. 6A and C), while caspase 8 activity was not significantly altered, compared with untreated control cells (Fig. 6B). These results indicate that BEA and CEA induce MDA-MB-231 apoptosis through the intrinsic pathway.

Effects of BEA and CEA treatment on Bcl-2 family mRNA expression levels. Bcl-2 family proteins play an important role in the mitochondrial pathway (57). Expression levels of NOXA and BAX were significantly increased in cells treated with BEA and CEA, whereas Bcl-xL mRNA expression levels were significantly attenuated compared with those of the control cells (Fig. 7). These results indicate that BEA and CEA induce NOXA expression, which subsequently downregulates Bcl-xL and upregulates BAX expression, inducing apoptosis.

Effects of BEA and CEA treatment on apoptotic-related protein expression levels. The expression levels of NOXA, BAX, Bcl-xL and cytochrome $c$ proteins were investigated in MDA-MB-231 cells following BEA and CEA treatment. Protein expression levels of NOXA and BAX were significantly increased, whereas Bcl-xL expression levels were significantly decreased following BEA and CEA treatment (Fig. 8). In addition, cytochrome $c$ expression levels were measured in the mitochondria and cytosol. Following treatment with BEA and CEA, cytochrome $c$ expression levels in the mitochondria decreased in a dose-dependent 
A

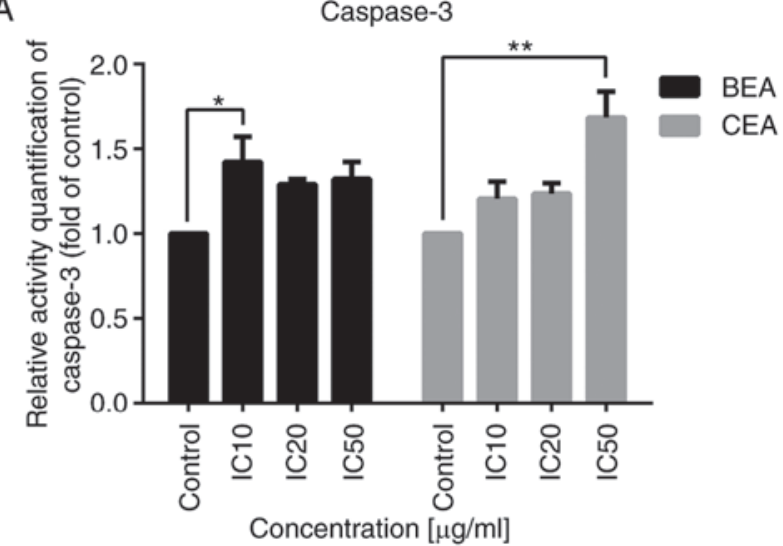

B

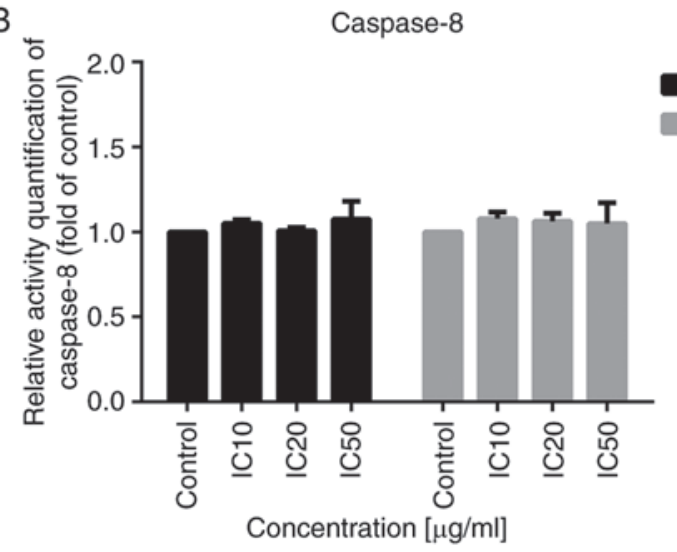

C

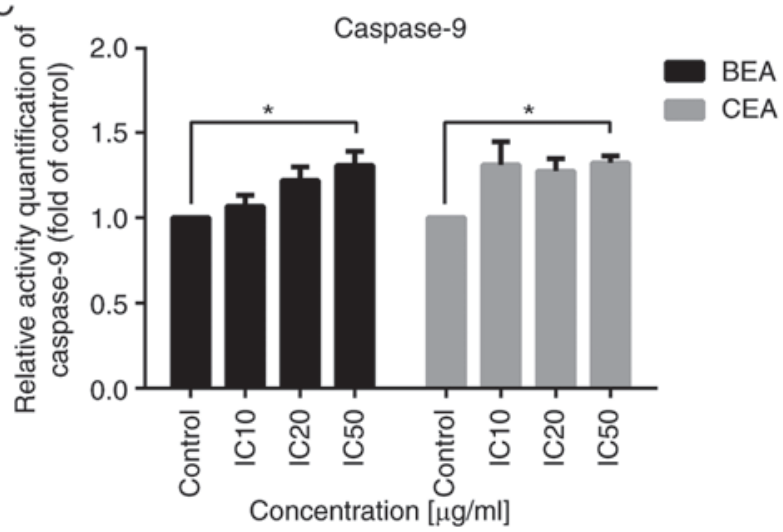

Figure 6. Caspase enzyme activity following BEA and CEA treatment. (A) Activities of caspase 3, (B) caspase 8 and (C) caspase 9 in MDA-MB-231 cells treated with BEA and CEA, and untreated control cells. The y-axis shows the level of caspase activity relative to the no-treatment control. ${ }^{*} \mathrm{P}<0.05$ and ${ }^{* *} \mathrm{P}<0.01$ vs. control. BEA, Bridelia ovata; CEA, Croton oblongifolius; IC, inhibitory concentration.

manner, while those in the cytosol were increased (Fig. 9). These results suggest that BEA and CEA induce the mitochondrial apoptosis pathway in MDA-MB-231 cells.

\section{Discussion}

B. ovata and C. oblongifolius are medicinal plants used in Thai traditional medicine. These herbs are used in the treatment of several diseases and symptoms, including as an expectorant (7), and to treat flatworm infections and dysmenorrhea (11). However, previous studies have also reported the cytotoxicity of these herbs against some cancer cell lines $(10,17)$. However, there are no reports investigating the underlying mechanisms of action of these two herbs for potential use in breast cancer treatment. In the present study, BEA and CEA were screened for the presence of phytoconstituent groups using standard methods. The phytochemical screening results showed several groups of phytochemical compounds, such as alkaloids, flavonoids, phytosterols and tannins. However, previous phytochemical reports of $B$. ovata showed the presence of triterpenoids and phytosterols, whereas those of $C$. oblongifolius revealed diterpenoids and megastigmane glycosides. Therefore, GC-MS analysis in the present study primarily aimed to identify triterpenoids, phytosterols and diterpenoids in BEA and CEA. To the best of our knowledge, this is first report of the phytoconstituents of crude ethyl acetate extracts of BEA and CEA by GC-MS analysis.

Friedelan-3-one is a friedelane-type triterpenoid, which was a primary phytoconstituent of BEA in the present study. A previous study reported the cytotoxic effect of friedelan-3-one against mouse 4T1 breast cancer cells (58). Friedelan-3-one also inhibits VEGF-induced Kaposi's sarcoma cell proliferation and induces apoptotic cell death (59). These findings indicate the cytotoxic effect and apoptotic induction of BEA in MDA-MB-231 cells, which may be associated with friedelan-3-one.

Kaur-16-en-18-oic acid (or kaurenoic acid) is a kaurane-type diterpenoid, which is present in some medicinal plants that possess potential anti-cancer properties (60). Kaurane diterpenes have been considered for the development of novel effective anti-cancer chemotherapeutic agents (61). Kaurenoic acid is also reported to possess apoptosis-inducing properties against various cell lines, including the HL-60 human leukemia cell line (62), the PC-3 human prostate cancer cell line and the A-549 human lung cancer cell line (63). Furthermore, the genotoxicity of kaurenoic acid has been demonstrated in gastric cancer cell lines, including ACP02, ACP03, AGP01 and PG100 (64), and cervical cancer cell lines such as HeLa, CaSki and C33A (65). Moreover, the epimer of kaurenoic acid isolated from Croton antisyphiliticus exhibits moderate cytotoxic activity against HeLa cervical cancer cells and B-16 murine melanoma cells, by inducing apoptosis (66).

In the present study, the second most abundant compound in both BEA and CEA was the phytosterol stigmast-5-en-3-ol. The anti-proliferative and pro-apoptotic effects of stigmast-5-en-3-ol (from Dendronephthya gigantean) have been demonstrated in HL-60 and MCF-7 cells (67). Diterpenes, triterpenes and phytosterols have shown anti-tumor activity in several models (68-71), hence they may have value as novel anti-tumor agents. In the present study, high contents of friedelan-3-one and stigmast-5-en-3-ol in BEA, and kaur-16-en-18-oic acid in CEA, were observed. Therefore, these two herbs show potential as anti-breast cancer agents.

However, in the present study, crude ethyl acetate extracts of $B$. ovata and $C$. oblongifolius were investigated for their anti-cancer activity as an alternative to purified forms of the constituents identified. The present study aimed to investigate all of the constituents in these herbal extracts on the basis of possible synergy required to generate the anti-cancer effects. A previous study demonstrated that the $\mathrm{IC}_{50}$ values of crude ethanolic extracts of B. ovata and C. oblongifolius in the HepG2 

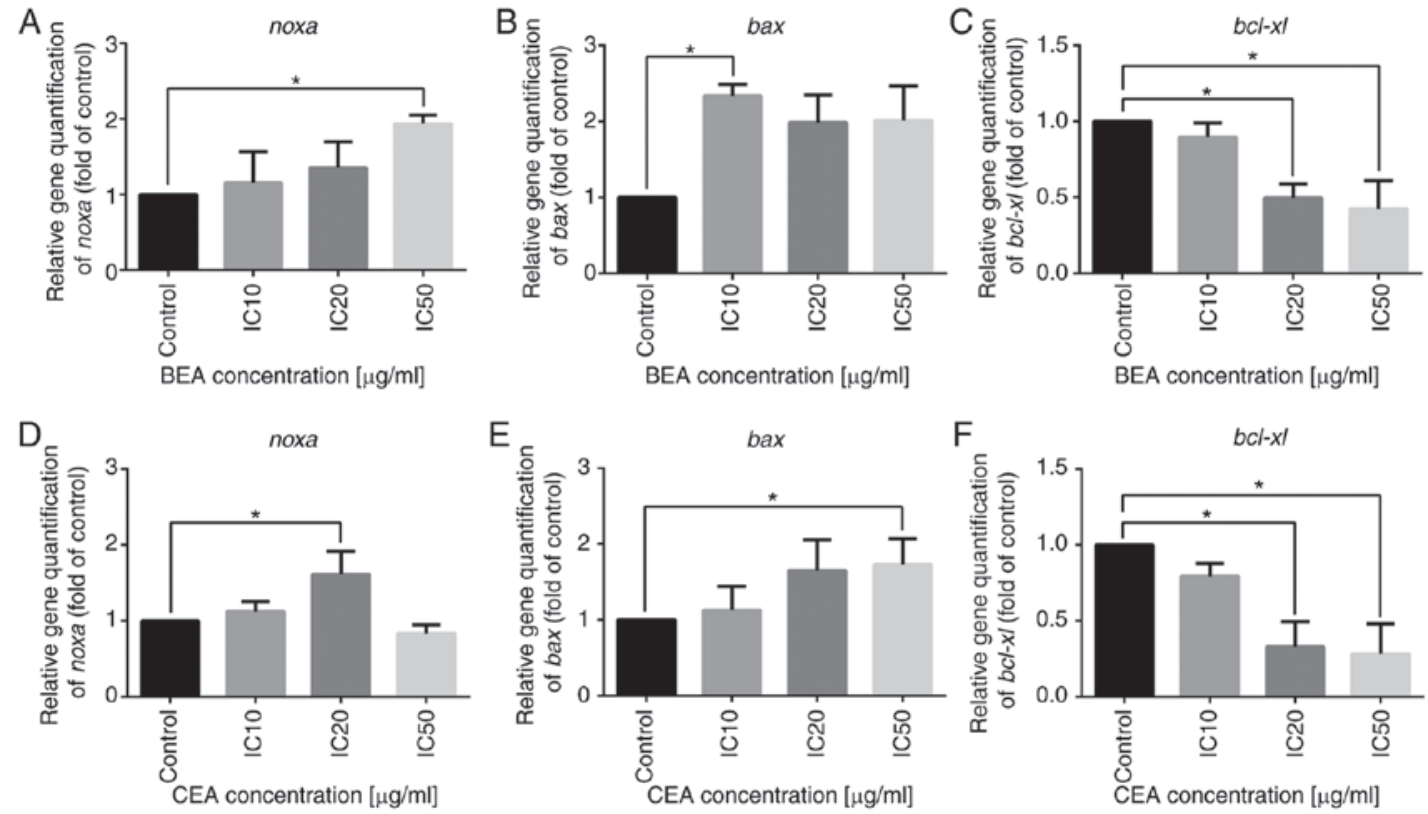

Figure 7. Expression of apoptotic genes after BEA and CEA treatment. MDA-MB-231 cells treated with (A-C) BEA and (D-F) CEA. The mRNA expression of NOXA, BAX and Bcl-xL was determined by reverse transcription-quantitative PCR. " $\mathrm{P}<0.05$ vs. the untreated control. BEA, Bridelia ovata; CEA, Croton oblongifolius; NOXA, phorbol-12-myristate-13-acetate-induced protein 1; BAX, Bcl2-associated X protein; Bcl-xL, B-cell lymphoma-extra large; IC, inhibitory concentration.
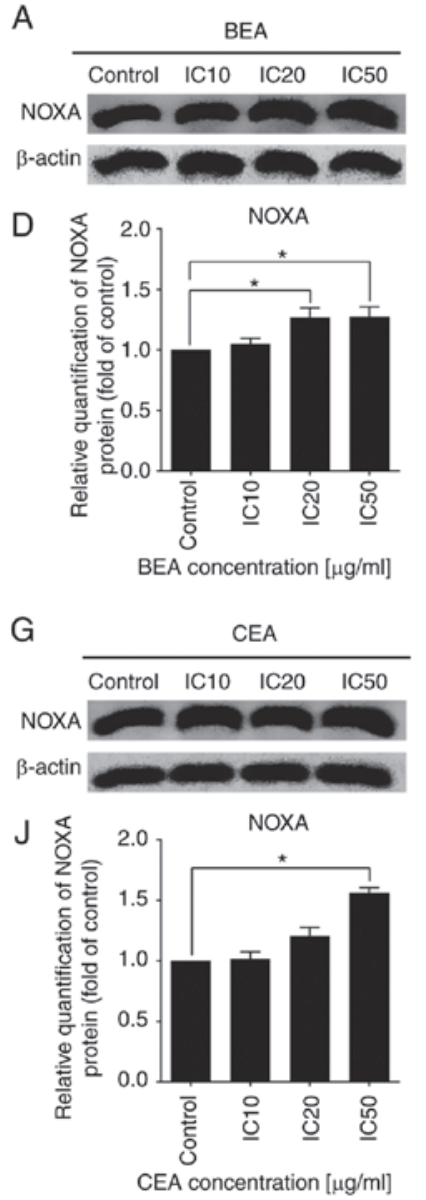

B

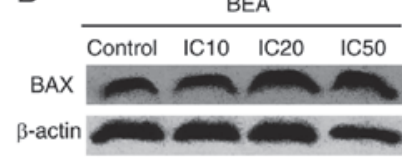

E

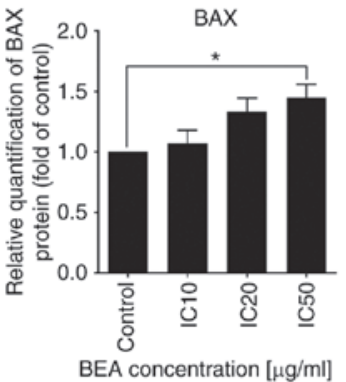

$\mathrm{H}$

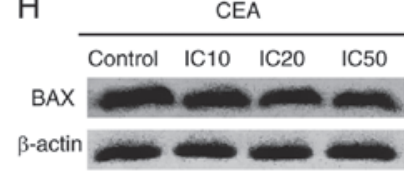

K

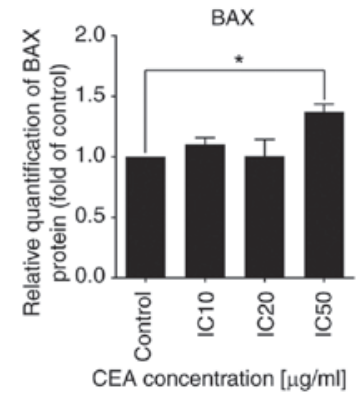

C

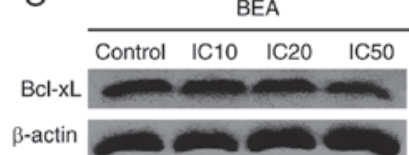

$F$

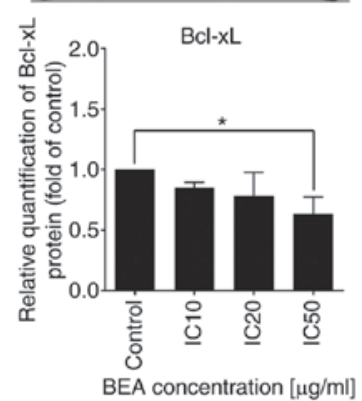

I

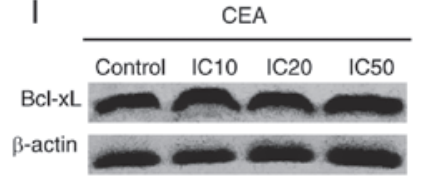

L

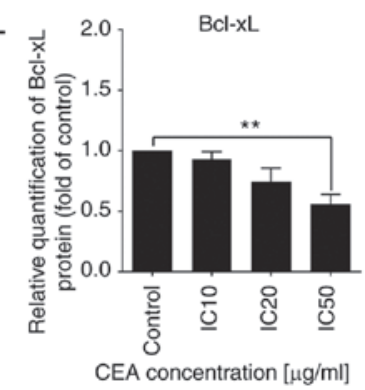

Figure 8. The effect of BEA and CEA on Bcl-2 family protein expression levels in MDA-MB-231 cells. BEA treatment increased the protein expression levels of (A) NOXA and (B) BAX, and deceased the protein expression levels of (C) Bcl-xL. Quantification of the protein band density for (D) NOXA, (E) BAX and (F) Bcl-xL after BEA treatment. CEA treatment increased the protein expression levels of (G) NOXA and (H) BAX, and decreased that of (I) Bcl-xL. Quantification of the protein band density for (J) NOXA, (K) BAX and (L) Bcl-xL after CEA treatment. " $\mathrm{P}<0.05$ and ${ }^{* *} \mathrm{P}<0.01$ vs. non-treated control MDA-MB-231 cells. BEA, Bridelia ovata; CEA, Croton oblongifolius; NOXA, phorbol-12-myristate-13-acetate-induced protein 1; BAX, Bcl2-associated X protein; Bcl-xL, B-cell lymphoma-extra large; IC, inhibitory concentration. 
A
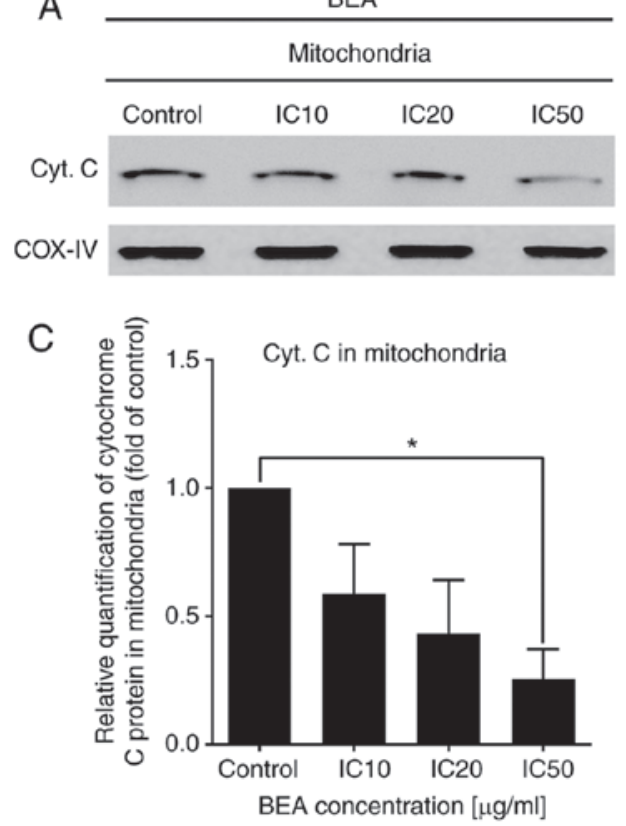

E
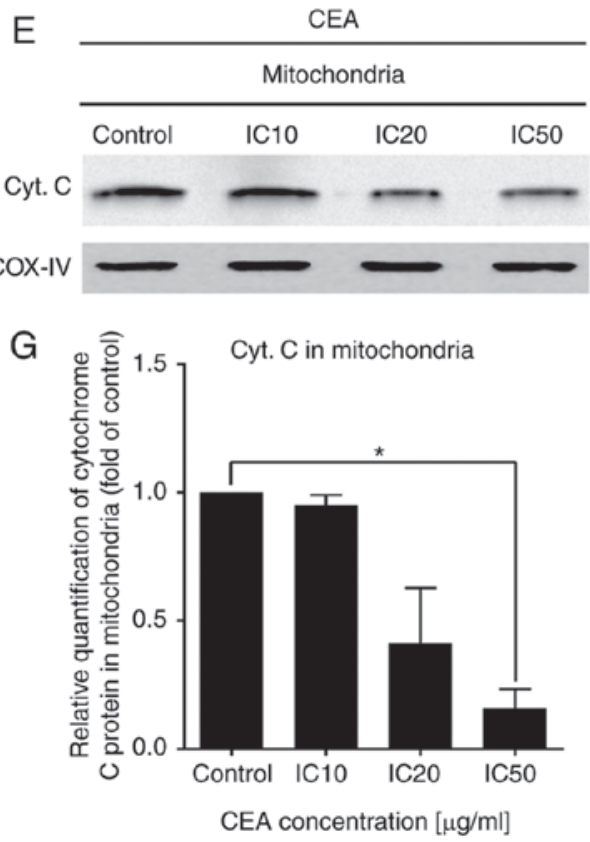

B
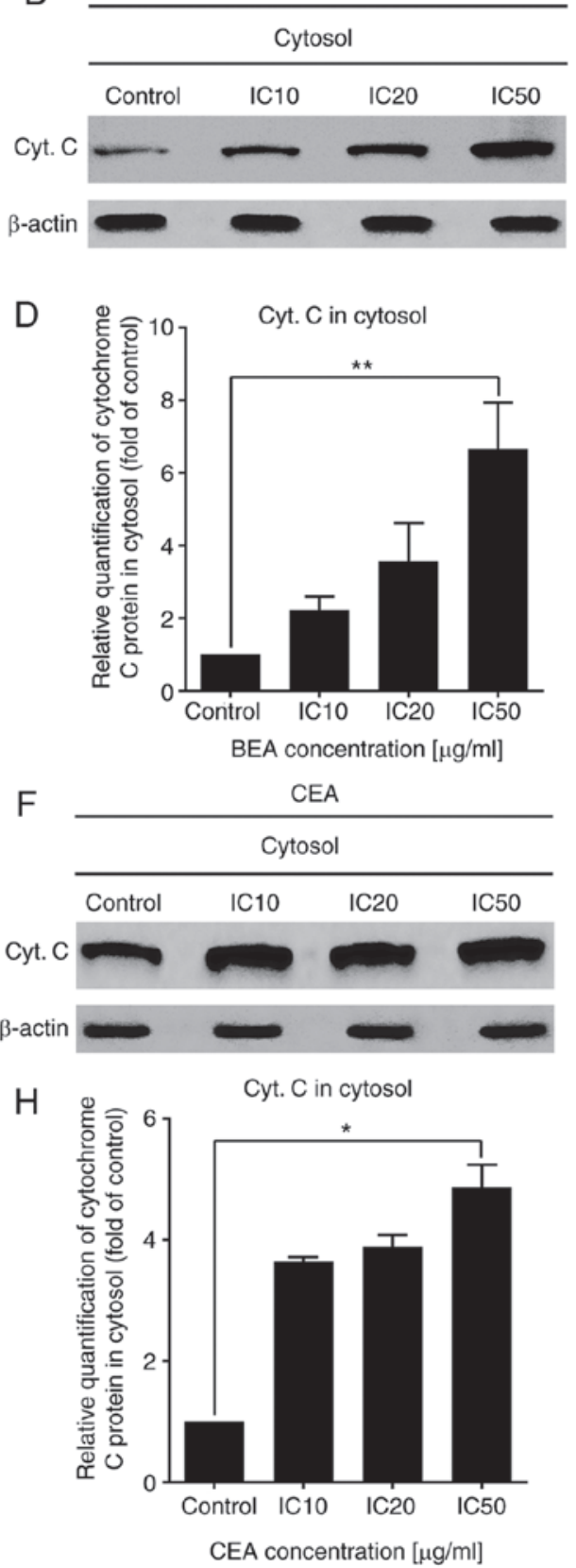

Figure 9. Alteration of Cyt. C protein levels in the mitochondria and cytosol following BEA and CEA treatment in MDA-MB-231 cells. Western blots for (A and B) BEA and (E and F) the CEA treatment. (C and G) BEA and CEA treatment decreased the protein expression levels of cytochrome $\mathrm{c}$ in the mitochondria. (D and H) BEA and CEA treatment increased the protein expression levels of cytochrome $\mathrm{c}$ in the cytosol. $\beta$-actin and COX-IV were used as internal controls for the cytosol and mitochondria, respectively. ${ }^{~} \mathrm{P}<0.05$ and ${ }^{* *} \mathrm{P}<0.01$ vs. respective control. Cyt. C, cytochrome C; BEA, Bridelia ovata; CEA, Croton oblongifolius; IC, inhibitory concentration.

cell line (72) were higher than the crude ethyl acetate extracts in the MDA-MB-231 cell line in the present study. These differences suggest that these two herbs have more potential as ethyl acetate extracts against breast cancer cells than ethanolic extracts against liver cancer; however, further study of these extracts against liver cancer is required. Comparing the $\mathrm{IC}_{50}$ and SI values of BEA and CEA suggests that CEA exerts greater toxic against MDA-MB-213 cells than BEA, whereas BEA acts more selectively towards breast cancer cells than CEA.

Annexin V-FITC and PI staining showed that MDA-MB-231 cells had undergone apoptosis and necrosis.
However, the number of necrotic cells was not significantly different compared with that of the control cells, and Rip3 protein expression levels did not change following BEA and CEA treatment. The percentage of apoptotic cells was significantly increased following treatment with both extracts in a dose-dependent manner, compared with that of the control cells.

The present study further investigated the mechanism of apoptosis, which revealed that the percentage of cells with mitochondrial disruption increased following treatment with both extracts. The mitochondria are the primary source of intracellular ROS production. High generation of ROS induces 


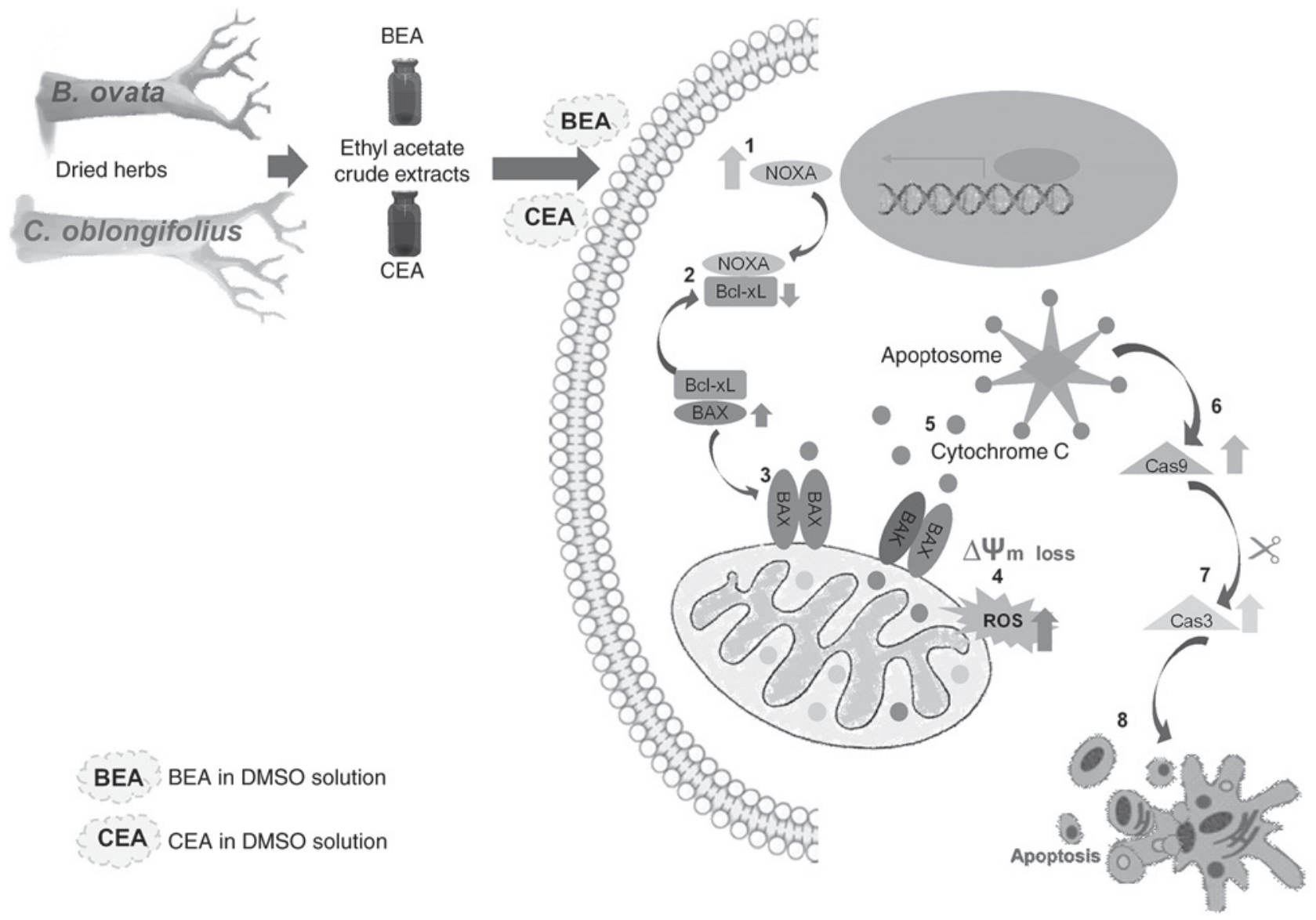

Figure 10. The apoptosis pathway induced by BEA and CEA in MDA-MB-231 cells. BEA and CEA induce gene and protein expression of NOXA and BAX pro-apoptotic proteins and reduced those of anti-apoptotic Bcl-xL, leading to the loss of mitochondrial membrane potential and ROS production. Cytochrome $\mathrm{c}$ is then released from the mitochondria into the cytosol, consequently inducing activation of the caspase 9 and 3 cascades, and ultimately resulting in apoptosis. BEA, Bridelia ovata; CEA, Croton oblongifolius; ROS, reactive oxygen species; Cas9, caspase 9; Cas3, caspase 3; $\Delta \Psi \mathrm{m}$, mitochondrial transmembrane potential; NOXA, phorbol-12-myristate-13-acetate-induced protein 1; BAX, Bcl2-associated X protein; Bcl-xL, B-cell lymphoma-extra large; DMSO, dimethyl sulfoxide.

mitochondrial dysfunction, cell damage and apoptosis (73). This $\Delta \Psi \mathrm{m}$ loss was associated with ROS generation, as the high energy source equates to the mitochondrial electron transport chain (74). Intracellular ROS induce cellular stress and consequently induce apoptosis (75). During apoptosis, the loss of mitochondrial membrane potential leads to the inhibition of ATP synthase, subsequently resulting in ROS production (76). However, a number of drugs and natural compounds can directly induce ROS generation; this includes doxorubicin, which also induces mitochondrial dysfunction and apoptosis $(77,78)$. In the present study, the level of ROS increased $\sim 1.5$-fold in MDA-MB-213 cells treated with BEA and CEA, compared with the control group, demonstrating that BEA and CEA induce oxidative stress, and subsequent apoptotic cell death. ROS level increased in a dose-independent manner, which may be due to the presence of antioxidants in the cell or the cellular microenvironment (79). Alternatively, this may be due to the oxidant content of the microenvironment, which contains superoxide dismutase (80), reduced glutathione (81), catalase, bilirubin, NADPH oxidase and lipoxygenase and toxins $(82,83)$.

Cellular stress can lead to DNA damage that activates the p53 tumor suppressor gene; this can induce apoptotic cell death and cell cycle arrest. However, the downstream effects of p53 activation depend on cell type, differentiation state and the local microenvironment (84). It has been reported that p53-mediated apoptosis is favorably selected in cells expressing oncoproteins (85); for example, mouse embryonic fibroblasts (MEFs) normally undergo p53-mediated cell cycle arrest, whereas MEFs expressing E1A oncoprotein undergo p53-mediated apoptosis (86). p53-mediated apoptosis involves the transcriptional targets PUMA and NOXA, and the expression of other BH-3 only proteins $(85,87)$. Several studies have reported that NOXA functions as an integral mediator of p53-dependent apoptosis (88). Moreover, PUMA and NOXA indirectly induce mitochondrial outer membrane permeabilization (MOMP) by direct binding to members of the anti-apoptotic Bcl-2 family, such as Bcl-2 and Bcl-xL, which interferes with pro-apoptotic BAX and BAK and anti-apoptotic interactions. Consequently, BAX serves a role in MOMP by homo- or heterodimerizing with BAK, forming pores in the mitochondrial outer membrane and permitting the release of cytochrome $c$ from the mitochondrial intermembranous space into the cytosol (89). This subsequently leads to the activation of initiator caspase 9, resulting in downstream activation of executioner caspase 3 , which proteolyzes key proteins, including those of cytoskeletal proteins. Also, caspase 3 inactivates other enzymes such as poly(ADP) ribose polymerase (PARP), a DNA repair enzyme (90). Finally, the cells undergo apoptotic cell death and exhibit unique morphological 
changes, including DNA fragmentation and membrane blebbing (91).

The present study investigated the effects of BEA and CEA on MDA-MB-231 human breast cancer cells, showing that treatment with these herbs increased the mRNA and protein expression levels of the pro-apoptotic proteins NOXA and BAX. By contrast, BEA and CEA treatment led to the downregulation of the anti-apoptotic protein Bcl-xL. Additionally, cytochrome $c$, which is essential for apoptosome formation and the progression of apoptosis (92), was released from the mitochondria into the cytosol. These data show that BEA and CEA induced breast cancer cell death via the mitochondria-mediated pathway. Caspases are a group of cysteine proteases which play a pivotal role in the apoptosis pathway (93). The mitochondrial dysfunction observed following BEA and CEA treatment demonstrated that only the intrinsic apoptotic pathway was activated by these herbs, and that there was no evidence of a significant increase in caspase 8 activity, which would indicate the activation of the extrinsic pathway. By contrast, significantly enhanced caspase 9 activity was observed. Caspase 3 activity was activated by active caspase 9, and this resulted in MDA-MB-231 cell apoptosis. Therefore, BEA and CEA induced apoptotic cell death via the mitochondrial apoptosis pathway.

To conclude, crude BEA and CEA extracts induced MDA-MB-231 human breast cancer cell apoptosis via oxidative stress and mitochondria-mediated pathways. The altered expression levels of NOXA, BAX and Bcl-xL resulted in disruption of the mitochondrial membrane potential and the release of cytochrome $c$ into the cytosol. This led to caspase 9 and 3 activation and induced apoptotic cell death. The pathway by which BEA and CEA induce MDA-MB-231 cell apoptosis is illustrated in Fig. 10. The lack of in vivo experiments using animal models and patient studies are the primary limitations of the present study. Therefore, further investigation into the associated active compounds in these extracts is required, and in vivo experiments need to be performed before these herbs can be developed as therapeutic agents for human breast cancer treatment.

\section{Acknowledgments}

The group would like to thank The Medical Science Research Equipment Center, Faculty of Medicine, Chiang Mai University.

\section{Funding}

The present study was supported by The Research and Researchers for Industries (grant no. PHD58I0008), and the Research Fund for Graduate Student of Faculty of Medicine, Chiang Mai University (grant no. 038/2018).

\section{Availability of data and materials}

The datasets used and/or analyzed during the present study are available from the corresponding author on reasonable request.

\section{Authors' contributions}

JP and RB designed the study. BS collected the herbs and took responsibility for the extraction. JP performed the biochemical experiments and wrote the manuscript. All authors read and approved the final manuscript.

\section{Ethical approval and consent to participate}

Not applicable.

\section{Patient consent for publication}

Not applicable.

\section{Competing interests}

The authors declare that they have no competing interests.

\section{References}

1. DeSantis CE, Ma J, Goding Sauer A, Newman LA and Jemal A: Breast cancer statistics, 2017, racial disparity in mortality by state. CA Cancer J Clin 67: 439-448, 2017.

2. Jemal A, Bray F, Center MM, Ferlay J, Ward E and Forman D: Global cancer statistics. CA Cancer J Clin 61: 69-90, 2011.

3. Sledge GW, Mamounas EP, Hortobagyi GN, Burstein HJ, Goodwin PJ and Wolff AC: Past, present, and future challenges in breast cancer treatment. J Clin Oncol 32: 1979-1986, 2014.

4. Moiseenko F, Volkov N, Bogdanov A, Dubina M and Moiseyenko V: Resistance mechanisms to drug therapy in breast cancer and other solid tumors: An opinion. F1000Res 6: 288, 2017.

5. Liu W, Fu X, Yang Z, Li S, Cao Y, Li Q and Luan J: Moderate intermittent negative pressure increases invasiveness of MDA-MB-231 triple negative breast cancer cells. Breast 38: $14-21,2018$

6. Sun L, Legood R, Dos-Santos-Silva I, Gaiha SM and Sadique Z: Global treatment costs of breast cancer by stage: A systematic review. PLoS One 13: e0207993, 2018.

7. Chotchoungchatchai S, Saralamp P, Jenjittikul T, Pornsiripongse S and Prathanturarug S: Medicinal plants used with thai traditional medicine in modern healthcare services: A case study in Kabchoeng Hospital, Surin Province, Thailand. J Ethnopharmacol 141: 193-205, 2012.

8. Boonyaratavej S, Tantayanontha S, Kitchanachai $\mathrm{P}$, Chaichantipyuth C, Chittawong V and Miles DH: Trans-triacontyl-4-hydroxy-3-methoxycinnamate, a new compound from the thai plant bridelia ovata. J Nat Prod 55: 1761-1763, 1992.

9. Thongkorn N: Chemical constituents of the leaves of bridelia ovata decne (unpublished $\mathrm{PhD}$ thesis). Chulalongkorn University, 1995.

10. Baig H, Diskul-Na-Ayudthaya P, Weeraphan C, Paricharttanakul M, Svasti J and Srisomsap C: Inhibitory effect of bridelia ovata decne extract on HepG2 cell migration and invasion stimulated by fibroblast-conditioned media. Naresuan Phayao J 1: 6-10, 2015.

11. Sommit D, Petsom A, Ishikawa T and Roengsumran S: Cytotoxic activity of natural labdanes and their semi-synthetic modified derivatives from Croton oblongifolius. Planta Med 69: 167-170, 2003.

12. Ngamrojnavanich N, Sirimongkon S, Roengsumran S, Petsom A and Kamimura $\mathrm{H}$ : Inhibition of $\mathrm{Na}+\mathrm{K}+$-ATPase activity by (-)-ent-Kaur-16-en-19-oic acid and its derivatives. Planta Med 69: 555-556, 2003.

13. Ahmed B, Alam T, Varshney M and Khan SA: Hepatoprotective activity of two plants belonging to the Apiaceae and the euphorbiaceae family. J Ethnopharmacol 79: 313-316, 2002.

14. Salatino A, Salatino MLF and Negri G: Traditional uses, chemistry and pharmacology of Croton species (Euphorbiaceae). J Braz Chem Soc 18: 11-33, 2007.

15. Singh M, Pal M and Sharma RP: Biological activity of the labdane diterpenes. Planta Med 65: 2-8, 1999.

16. Takeshige Y, Kawakami S, Matsunami K, Otsuka H, Lhieochaiphant D and Lhieochaiphant S: Oblongionosides A-F, megastigmane glycosides from the leaves of Croton oblongifolius Roxburgh. Phytochemistry 80: 132-136, 2012. 
17. Roengsumran S, Petsom A, Kuptiyanuwat N, Vilaivan T, Ngamrojnavanich $\mathrm{N}$, Chaichantipyuth $\mathrm{C}$ and Phuthong S: Cytotoxic labdane diterpenoids from Croton oblongifolius. Phytochemistry 56: 103-107, 2001

18. Pudhom K and Sommit D: Clerodane diterpenoids and a trisubstituted furan from Croton oblongifolius. Phytochem Lett 4: 147-150, 2011.

19. Roengsumran S, Musikul K, Petsom A, Vilaivan T, Sangvanich P, Pornpakakul S, Puthong S, Chaichantipyuth C, Jaiboon N and Chaichit N: Croblongifolin, a new anticancer clerodane from Croton oblongifolius. Planta Med 68: 274-277, 2002.

20. Youngsa-ad W, Ngamrojanavanich N, Mahidol C, Ruchirawat S, Prawat H and Kittakoop P: Diterpenoids from the roots of Croton oblongifolius. Planta Med 73: 1491-1494, 2007.

21. Pudhom K, Vilaivan T, Ngamrojanavanich N, Dechangvipart S, Sommit D, Petsom A and Roengsumran S: Furanocembranoids from the stem bark of Croton oblongifolius. J Nat Prod 70 659-661, 2007.

22. Roengsumran S, Pornpakakul S, Muangsin N, Sangvanich P, Nhujak T, Singtothong P, Chaichit N, Puthong S and Petsom A: New halimane diterpenoids from Croton oblongifolius. Planta Med 70: 87-89, 2004

23. Roengsumran S, Achayindee S, Petsom A, Pudhom K, Singtothong P, Surachetapan C and Vilaivan T: Two new cembranoids from Croton oblongifolius. J Nat Prod 61: 652-654, 1998.

24. Roengsumran S, Singtothong P, Pudhom K Ngamrochanavanich N, Petsom A and Chaichantipyuth C: Neocrotocembranal from Croton oblongifolius. J Nat Prod 62: 1163-1164, 1999.

25. Suwancharoen S, Tommeurd W, Phurat C, Muangsin N and Pornpakakul S: Acanthoic acid. Acta Crystallogr Sect E Struct Rep Online 66: o1531, 2010.

26. Renehan AG, Booth C and Potten CS: What is apoptosis, and why is it important? BMJ 322: 1536-1538, 2001.

27. Favaloro B, Allocati N, Graziano V, Di Ilio C and De Laurenzi V: Role of apoptosis in disease. Aging (Albany N Y) 4: 330-349, 2012.

28. Fathi N, Rashidi G, Khodadadi A, Shahi S and Sharifi S: STAT3 and apoptosis challenges in cancer. Int J Biol Macromol 117: 993-1001, 2018.

29. Kumar R, Herbert PE and Warrens AN: An introduction to death receptors in apoptosis. Int J Surg 3: 268-277, 2005.

30. O'Brien MA and Kirby R: Apoptosis: A review of pro-apoptotic and anti-apoptotic pathways and dysregulation in disease. J Veterinary Emergency Crit Care 18: 572-585, 2008.

31. Schneider P and Tschopp J: Apoptosis induced by death receptors. Pharm Acta Helv 74: 281-286, 2000.

32. Chinnaiyan AM: The apoptosome: Heart and soul of the cell death machine. Neoplasia 1: 5-15, 1999.

33. Tait SW and Green DR: Mitochondria and cell death: Outer membrane permeabilization and beyond. Nat Rev Mol Cell Biol 11: 621-632, 2010.

34. Cao K and Tait SWG: Apoptosis and cancer: Force awakens, phantom menace, or both? Int Rev Cell Mol Biol 337: 135-152, 2018.

35. Dong N, Liu X, Zhao T, Wang L, Li H, Zhang S, Li X, Bai X, Zhang Y and Yang B: Apoptosis-inducing effects and growth inhibitory of a novel chalcone, in human hepatic cancer cells and lung cancer cells. Biomed Pharmacother 105: 195-203, 2018.

36. Neve RM, Chin K, Fridlyand J, Yeh J, Baehner FL, Fevr T, Clark L, Bayani N, Coppe JP, Tong F, et al: A collection of breast cancer cell lines for the study of functionally distinct cancer subtypes. Cancer Cell 10: 515-527, 2006.

37. Dai X, Cheng H, Bai Z and Li J: Breast cancer cell line classification and its relevance with breast tumor subtyping. J Cancer 8: 3131-3141, 2017.

38. Chen X and Thibeault S: Effect of DMSO concentration, cell density and needle gauge on the viability of cryopreserved cells in three dimensional hyaluronan hydrogel. Conf Proc IEEE Eng Med Biol Soc 2013: 6228-6231, 2013.

39. Arega ED: Phytochemical studies of the ethyl acetate extract of the fruit of piper capense. J Pharm Nat Products 4: 148-152, 2018.

40. Obasi NL, Egbuonu ACC, Ukoha PO and Ejikeme PM: Comparative phytochemical and antimicrobial screening of some solvent extracts of Samanea saman (fabaceae or mimosaceae) pods. Afr J Pure Appl Chem 4: 206-212,2010.

41. Tiwari P, Kumar B, Kaur M, Kaur G and Kaur H: Phytochemical screening and extraction: A review. Int Pharm Sci 1: 98-106, 2011.
42. Banjerdpongchai R, Yingyurn S and Kongtawelert P: Sesamin induces human leukemic cell apoptosis via mitochondrial and endoplasmic reticulum stress pathways. World J Oncol 1: 78-86, 2010.

43. Wudtiwai B, Sripanidkulchai B, Kongtawelert P and Banjerdpongchai R: Methoxyflavone derivatives modulate the effect of TRAIL-induced apoptosis in human leukemic cell lines. J Hematol Oncol 4: 52, 2011.

44. Khaw-on P and Banjerdpongchai R: Induction of intrinsic and extrinsic apoptosis pathways in the human leukemic MOLT-4 cell line by terpinen-4-ol. Asian Pac J Cancer Prev 13: 3073-3076, 2012.

45. Khaw-On P,Pompimon W and Banjerdpongchai R: Goniothalamin induces necroptosis and anoikis in human invasive breast cancer MDA-MB-231 cells. Int J Mol Sci 20: E3953, 2019.

46. Dikalov S, Griendling KK and Harrison DG: Measurement of reactive oxygen species in cardiovascular studies. Hypertension 49: 717-727, 2007.

47. Zhao H, Kalivendi S, Zhang H, Joseph J, Nithipatikom K, Vásquez-Vivar J and Kalyanaraman B: Superoxide reacts with hydroethidine but forms a fluorescent product that is distinctly different from ethidium: Potential implications in intracellular fluorescence detection of superoxide. Free Radic Biol Med 34: 1359-1368, 2003

48. Livak KJ and Schmittgen TD: Analysis of relative gene expression data using real-time quantitative PCR and the 2(-Delta Delta C(T)) method. Methods 25: 402-408, 2001.

49. Mitas M, Mikhitarian K, Walters C, Baron PL, Elliott BM, Brothers TE, Robison JG, Metcalf JS, Palesch YY, Zhang Z, et al: Quantitative real-time RT-PCR detection of breast cancer micrometastasis using a multigene marker panel. Int J Cancer 93: 162-171, 2001.

50. Hanf A, Oelze M, Manea A, Li H, Munzel T and Daiber A: The anti-cancer drug doxorubicin induces substantial epigenetic changes in cultured cardiomyocytes. Chem Biol Interact 313: 108834,2019

51. Wudtiwai B, Pitchakarn $\mathrm{P}$ and Banjerdpongchai $\mathrm{R}$ : Alpha-mangostin, an active compound in Garcinia mangostana, abrogates anoikis-resistance in human hepatocellular carcinoma cells. Toxicol In Vitro 53: 222-232, 2018.

52. Badisa RB, Darling-Reed SF, Joseph P, Cooperwood JS, Latinwo LM and Goodman CB: Selective cytotoxic activities of two novel synthetic drugs on human breast carcinoma MCF-7 cells. Anticancer Res 29: 2993-2996, 2009.

53. Prayong P, Barusrux S and Weerapreeyakul N: Cytotoxic activity screening of some indigenous Thai plants. Fitoterapia 79: 598-601, 2008.

54. Rivankar S: An overview of doxorubicin formulations in cancer therapy. J Cancer Res Ther 10: 853-858, 2014.

55. Kalogeris T, Bao Y and Korthuis RJ: Mitochondrial reactive oxygen species: A double edged sword in ischemia/reperfusion vs. preconditioning. Redox Biol 2: 702-714, 2014

56. Kalyanaraman B, Darley-Usmar V, Davies KJ, Dennery PA, Forman HJ, Grisham MB, Mann GE, Moore K, Roberts LJ II and Ischiropoulos $\mathrm{H}$ : Measuring reactive oxygen and nitrogen species with fluorescent probes: Challenges and limitations. Free Radic Biol Med 52: 1-6, 2012.

57. Tsujimoto Y: Role of $\mathrm{Bcl}-2$ family proteins in apoptosis: Apoptosomes or mitochondria? Genes Cells 3: 697-707, 1998

58. Sousa GFd, Soares DCF, Mussel WdN, Pompeu NFE, Silva GDdF, Vieira Filho SA and Duarte LP: Pentacyclic triterpenes from branches of Maytenus robusta and in vitro cytotoxic property against 4T1 cancer cells. J Braz Chem Soc 25: 1338-1345, 2014.

59. Martucciello S, Balestrieri ML, Felice F, Estevam Cdos S, Sant'Ana AE, Pizza C and Piacente S: Effects of triterpene derivatives from Maytenus rigida on VEGF-induced Kaposi's sarcoma cell proliferation. Chem Biol Interact 183: 450-454, 2010.

60. Balbinot RB, de Oliveira JAM, Bernardi DI, Melo UZ, Zanqueta ÉB, Endo EH, Ribeiro FM, Volpato H, Figueiredo MC, Back DF, et al: Structural characterization and biological evaluation of 18-Nor-ent-labdane diterpenoids from grazielia gaudichaudeana. Chem Biodivers 16: e1800644, 2019.

61. Cavalcanti BC, Ferreira JR, Moura DJ, Rosa RM, Furtado GV, Burbano RR, Silveira ER, Lima MA, Camara CA, Saffi J, et al: Structure-mutagenicity relationship of kaurenoic acid from Xylopia sericeae (Annonaceae). Mutat Res 701: 153-163, 2010.

62. Cavalcanti BC, Bezerra DP, Magalhães HI, Moraes MO, Lima MA, Silveira ER, Câmara CA, Rao VS, Pessoa C and Costa-Lotufo LV: Kauren-19-oic acid induces DNA damage followed by apoptosis in human leukemia cells. J Appl Toxicol 29: $560-568,2009$ 
63. Cuca LE, Coy ED, Alarcón MA, Fernández A and Aristizábal FA Cytotoxic effect of some natural compounds isolated from Lauraceae plants and synthetic derivatives. Biomedica 31: 335-343, 2011

64. Cardoso PCDS, Rocha CAMD, Leal MF, Bahia MO, Alcântara DDFÁ, Santos RAD, Gonçalves NDS, Ambrósio SR Cavalcanti BC, Moreira-Nunes CA, et al: Effect of diterpenoid kaurenoic acid on genotoxicity and cell cycle progression in gastric cancer cell lines. Biomed Pharmacother 89: 772-780, 2017.

65. Rocha SMMD, Cardoso PCDS, Bahia MO, Pessoa CDÓ, Soares PC, Rocha SMD, Burbano RMR and Rocha CAMD Effect of the kaurenoic acid on genotoxicity and cell cycle progression in cervical cancer cells lines. Toxicol In Vitro 57: 126-131, 2019

66. Fernandes VC, Pereira SI, Coppede J, Martins JS, Rizo WF, Beleboni RO, Marins M, Pereira PS, Pereira AM and Fachin AL: The epimer of kaurenoic acid from Croton antisyphiliticus is cytotoxic toward B-16 and HeLa tumor cells through apoptosis induction. Genet Mol Res 12: 1005-1011, 2013.

67. Fernando IPS, Sanjeewa KKA, Ann YS, Ko CI, Lee SH, Lee WW and Jeon YJ: Apoptotic and antiproliferative effects of Stigmast-5-en-3-ol from Dendronephthya gigantea on human leukemia HL-60 and human breast cancer MCF-7 cells. Toxicol In Vitro 52: 297-305, 2018

68. Jian B, Zhang H, Han C and Liu J: Anti-cancer activities of diterpenoids derived from Euphorbia fischeriana steud. Molecules 23: E387, 2018.

69. Petiwala SM and Johnson JJ: Diterpenes from rosemary (Rosmarinus officinalis): Defining their potential for anti-cancer activity. Cancer Lett 367: 93-102, 2015.

70. Suttiarporn P, Chumpolsri W, Mahatheeranont S, Luangkamin S, Teepsawang S and Leardkamolkarn V: Structures of phytosterols and triterpenoids with potential anti-cancer activity in bran of black non-glutinous rice. Nutrients 7: 1672-1687, 2015.

71. Saleem M: Lupeol, a novel anti-inflammatory and anti-cancer dietary triterpene. Cancer Lett 285: 109-115, 2009.

72. Weerapreeyakul N, Nonpunya A, Barusrux S, Thitimetharoch T and Sripanidkulchai B: Evaluation of the anticancer potential of six herbs against a hepatoma cell line. Chin Med 7: 15, 2012.

73. Sinha K, Das J, Pal PB and Sil PC: Oxidative stress: The mitochondria-dependent and mitochondria-independent pathways of apoptosis. Arch Toxicol 87: 1157-1180, 2013.

74. Cairns RA, Harris IS and Mak TW: Regulation of cancer cell metabolism. Nat Rev Cancer 11: 85-95, 2011.

75. Circu ML and Aw TY: Reactive oxygen species, cellular redox systems, and apoptosis. Free Radic Biol Med 48: 749-762, 2010.

76. Redza-Dutordoir M and Averill-Bates DA: Activation of apoptosis signalling pathways by reactive oxygen species. Biochim Biophys Acta 1863: 2977-2992, 2016.

77. He H, Zang LH, Feng YS, Chen LX, Kang N, Tashiro S, Onodera S, Qiu F and Ikejima T: Physalin A induces apoptosis via p53-Noxa-mediated ROS generation, and autophagy plays a protective role against apoptosis through $\mathrm{p} 38-\mathrm{NF}-\mathrm{kB}$ survival pathway in A375-S2 cells. J Ethnopharmacol 148: 544-555, 2013.
78. Yu CC, Ko FY, Yu CS, Lin CC, Huang YP, Yang JS, Lin JP and Chung JG: Norcantharidin triggers cell death and DNA damage through S-phase arrest and ROS-modulated apoptotic pathways in TSGH 8301 human urinary bladder carcinoma cells. Int J Oncol 41: 1050-1060, 2012.

79. Weinberg F, Ramnath $\mathrm{N}$ and Nagrath D: Reactive oxygen species in the tumor microenvironment: An overview. Cancers (Basel) 11: E1191, 2019.

80. Crompton M: The mitochondrial permeability transition pore and its role in cell death. Biochem J 341: 233-249, 1999.

81. Griffith OW: Biologic and pharmacologic regulation of mammalian glutathione synthesis. Free Radic Biol Med 27: 922-935, 1999.

82. Komonrit $\mathrm{P}$ and Banjerdpongchai R: Effect of Pseuderanthemum palatiferum (Nees) radlk fresh leaf ethanolic extract on human breast cancer MDA-MB-231 regulated cell death. Tumour Biol 40: 1010428318800182, 2018.

83. Kumari S, Badana AK, G MM, G S and Malla R: Reactive oxygen species: A key constituent in cancer survival. Biomark Insights 13: 1177271918755391, 2018.

84. Kastenhuber ER and Lowe SW: Putting p53 in context. Cell 170: 1062-1078, 2017

85. Vousden KH and Lu X: Live or let die: The cell's response to p53. Nat Rev Cancer 2: 594-604, 2002.

86. Lowe SW, Ruley HE, Jacks T and Housman DE: p53-dependent apoptosis modulates the cytotoxicity of anticancer agents. Cell 74: 957-967, 1993.

87. Shibue T, Suzuki S, Okamoto H, Yoshida H, Ohba Y, Takaoka A and Taniguchi T: Differential contribution of Puma and Noxa in dual regulation of p53-mediated apoptotic pathways. EMBO J 25: 4952-4962, 2006.

88. Shibue T, Takeda K, Oda E, Tanaka H, Murasawa H, Takaoka A, Morishita Y, Akira S, Taniguchi T and Tanaka N: Integral role of Noxa in p53-mediated apoptotic response. Genes Dev 17: 2233-2238, 2003

89. Zhang LN, Li JY and Xu W: A review of the role of Puma, Noxa and Bim in the tumorigenesis, therapy and drug resistance of chronic lymphocytic leukemia. Cancer Gene Ther 20: 1-7, 2013.

90. Mcllwain DR, Berger T and Mak TW: Caspase functions in cell death and disease. Cold Spring Harb Perspect Biol 5: a008656, 2013.

91. Saraste A and Pulkki K: Morphologic and biochemical hallmarks of apoptosis. Cardiovasc Res 45: 528-537, 2000.

92. Huttemann M, Pecina P, Rainbolt M, Sanderson TH, Kagan VE, Samavati L, Doan JW and Lee I: The multiple functions of cytochrome $\mathrm{c}$ and their regulation in life and death decisions of the mammalian cell: From respiration to apoptosis. Mitochondrion 11: 369-381, 2011.

93. Salvesen GS: Caspases and apoptosis. Essays Biochem 38: 9-19, 2002. 